\title{
Chapter
}

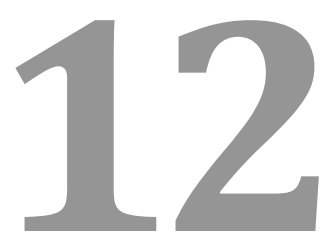

STRONG BIODEGRADABILITY OF VINYL POLYMERS EXERTED BY INSERTION OF $N$-BENZYL-4-VINYL-PYRIDINIUM HALIDE INTO THE MAIN CHAIN

\section{Nariyoshi Kawabata}

Kyoto Institute of Technology, Kyoto 606-8585, Japan University of Shiga Prefecture, Shiga 522-8533, Japan 


\section{Contents}

12.1. INTRODUCTION

12.2. POWERFUL CAPTURE OF BACTERIAL CELLS IN THE LIVING STATE ON THE SURFACE OF CROSS-LINKED PBVP(Br)

12.2.1. Accidental discovery of powerful capture of bacterial cells by crosslinked PBVP(Br).

12.2.2. Inducement to attempt removal of bacteria from water with use of cross-linked PBVP(Br)

12.2.3. Influence of chemical structure of cross-linked PBVP(Br) on the ability to capture bacterial cells

12.2.4. Affinity of bacterial cells with cross-linked PBVP(Br).

12.2.5. Bioreactor using bacterial cells immobilized by capture on the surface of cross-linked PBVP(Br)

12.2.6. Removal of bacteria and virus by filtration through composite microporous membrane made of cross-linked PBVP(Cl)

12.3. STRONG ACTION OF LINEAR POLY( $N$-BENZYL-4-VINYLPYRIDINIUM HALIDE) UPON MICROBIAL CELLS.

12.3.1. Strong antibacterial activity of linear PBVP(Br)

12.3.2. Removal of bacteria from water by coagulation and sedimentation using linear PBVP(Br) and PBVP(Cl) and their copolymers

12.3.3. Removal of micro-organisms by filtration through unwoven cloth coated with copolymer of styrene with BVP(Cl)

12.3.4. Electrochemical sensor for viable microbial cell concentration using copolymer of styrene with BVP(Cl).

12.3.5. Bioreactor using bacterial cells immobilized on the surface of unwoven cloth coated with copolymer of styrene with BVP(Cl)

12.3.6. Control of soil-borne plant diseases by capture of disease germs using sawdust coated with copolymer of styrene with BVP(Cl)...

12.3.7. Suppression of soil-borne plant disease by coagulation of disease germs using copolymer of methyl methacrylate with $\mathrm{BVP}(\mathrm{Cl})$.

12.4. VIOLENT DIGESTION OF CROSS-LINKED PBVP(Br) BY ACTIVATED SLUDGE

12.4.1. Miserably complete failure of using cross-linked $\mathrm{PBVP}(\mathrm{Br})$ as a filter medium for bio-film process of sewage treatment

12.4.2. Essence of biodegradability of polymers that harmonized with recycling system of materials in the natural environment.

12.5. BIODEGRABILITY OF POLY(METHYL METHACRYLATE) (PMMA) THAT CONTAINS BVP(Cl) IN THE MAIN CHAIN.

12.6. BIODEGRADABILITY OF POLY(VINYL ACETATE) THAT CONTAINS BVP(Cl) IN THE MAIN CHAIN.

12.7. BIODEGRABILITY OF POLY(ACRYLAMIDE) THAT CONTAINS BVP(CI) IN THE MAIN CHAIN 
12.8. BIODEGRABILITY OF POLYSTYRENE THAT CONTAINS BVP(Cl) IN THE MAIN CHAIN

12.9. BIODEGRABILITY OF POLY(ACRYLONITRILE) THAT CONTAINS BVP(CI) IN THE MAIN CHAIN.

12.10. RECYCLING USE OF SYNTHETIC POLYMERS WITHOUT LEAVING WASTES INTO NATURAL ENVIRONMENT.

12.10.1. Zero-emission use of synthetic polymers to prevent pollution of natural environment by wasted synthetic polymers

12.10.2. Grade of recycling use of synthetic polymers 430

12.10.3. Closely connected cooperation of artery industry with venous industry required by efficient recycling of resource materials 431 



\subsection{INTRODUCTION}

Research results and activities of chemists are splendid, but they should become conscious of their severe duty to protect natural abundant environment from pollution by synthetic chemical materials that have no existence in nature as appealed by "Silent Spring" authored by Rachel Carson in 1962 and "Our Stolen Future" authored by Theo Colborn, Dianne Dumanoski and John P. Myers in 1996. Inadequate and antisocial use of synthetic harmful chemical material has been considerably improved by strong pressure of public opinion.

However, improvement of the use of troublesome chemical materials produced by chemists and chemical industry is very slow. Most serious subject of chemists and chemical industry is environmental pollution by wastes consisted of poorly biodegradable chemical materials produced by chemical industry. For example, plastic wastes lacked of biodegradability powerfully injury wildlife [1]. Poorly biodegradable plastic wastes were found in the internal organs of dead bodies of wild birds. Recent newspaper reported that microplastics were found in the internal organs of $80 \%$ of sardines captured in Tokyo bay in 2015. This serious situation is a severe punishment for superficial understanding of society that enlarged easygoing abandonment of poorly biodegradable plastic wastes.

Improvement of the above environmental pollution by using biodegradable polymers has received increasing attention. However, development of synthetic biodegradable polymers is insufficient, because utility is much more important than biodegradability for users of synthetic polymers, and utilities of biodegradable synthetic polymers are limited. Grant of biodegradability to useful synthetic polymers is a greatly important subject for polymer chemists. In the cases where grant of biodegradability is difficult or durability of synthetic polymers is absolutely important, retrenchment of wastes of synthetic polymers is inevitable. Protection of abundant environment from pollution by poorly biodegradable wastes of synthetic polymers requires construction of zero-emission system by conversion of one-way use of synthetic polymers that leaves wastes to recycling use of synthetic polymers that decreases wastes of synthetic polymers. Recycling use is not uniform, and grade up of recycling use is necessary for the retrenchment of wastes of synthetic polymers.

My research group accidentally discovered powerful capture of bacteria in the living state on the surface of cross-linked poly( $N$-benzyl-4-vinylpyridinium bromide) (PBVP(Br)), during our development of novel technology for water purification without leaving harmful chemical materials in the treated water. During this research, we encountered with violent proliferation of bacteria on the polymer surface which was covered with proliferated bacterial cells that 
resembled a group of breeding mold, although there was no organic material other than the polymer and bacteria. We overlooked the great significance of proliferation of bacteria on the polymer surface at that time. After about ten years, we were shocked by violent digestion of cross-linked PBVP(Br) by activated sludge when placed in continuous aerobic treatment system of artificial sewage by activated sludge.

Stimulated by this shocking occurrence, we tried to prepare biodegradable vinyl polymers by connection of oligomers of vinyl compounds by $N$-benzyl-4vinylpyridinium chloride (BVP(Cl)), since oligomers of vinyl compounds are biodegradable different from high molecular weight vinyl polymers.

Since the role of BVP is fundamentally significant in the exertion of strong biodegradability to vinyl polymers by insertion of BVP into the main chain, I describe the conspicuous character of vinyl polymers that contain BVP in the main chain before explanation of biodegradability of these polymers. Especially important character of BVP is extraordinary strong affinity with the surface of bacteria and virus. This affinity is supported by strong hydrophilicity of BVP.

I describe a variety of eccentric utilities of vinyl polymers that contain BVP in the main chain, because utility is much more important than biodegradability for users of synthetic polymers.

\subsection{POWERFUL CAPTURE OF BACTERIAL CELLS IN THE LIVING STATE ON THE SURFACE OF CROSS-LINKED PBVP(Br)}

\subsubsection{Accidental discovery of powerful capture of bacterial cells by cross-linked PBVP(Br)}

My research group accidentally discovered powerful capture of bacterial cells in the living state by cross-linked PBVP(Br), during eccentric development of new technology for water purification using insoluble resins without leaving harmful chemical materials such as trihalomethane in the treated water [2]. Figure 1 shows examples of powerful removal of bacterial cells from water by cross-linked PBVP(Br). Batch studies of the removal of Escherichia coli, Salmonella typhimurium, Staphylococcus aureus, Streptococcus faecalis, and Pseudomonas aeruginosa were carried out using a glass tube (28 by $100 \mathrm{~mm}$ ) at $37^{\circ} \mathrm{C}$. In the glass tube was placed $20 \mathrm{~mL}$ of each bacterial suspension in sterilized saline, and added $10 \mathrm{~g}$ (wet weight) of cross-linked PBVP(Br). About $99 \%$ removal of the viable cells of E. coli, S. aureus, S. faecalis and P. aeruginosa was achieved during $2 \mathrm{~h}$. However, $99 \%$ removal of $S$. typhimurium was achieved after about $6 \mathrm{~h}$. 


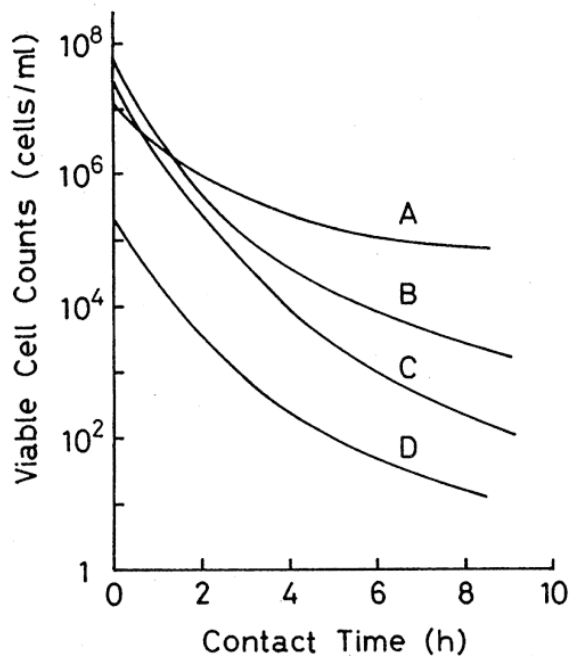

Figure 1. Removal of viable cells of various bacteria from water by cross-linked PBVP(Br): A - Salmonella typhimurium; B - Staphylococcus aureus; C - Streptococcus faecalis; D - Pseudomonas aeruginosa

We also discovered powerful capture of bacteriophage T4 [3] and pathogenic human viruses [4] by cross-linked PBVP(Br). Adsorption of bacteriophage T4 by cross-linked PBVP(Br) was performed by batch studies under aseptic conditions. Adsorption of bacteriophage T4 reached $99.9999 \%$ reduction of virus infectivity during $2 \mathrm{~h}$ when used $4.0 \mathrm{~mL}$ of T4 phage solution and $0.38 \mathrm{~g}$ of the polymer at $25^{\circ} \mathrm{C}$. The T4 phage adsorbed by the polymer was still bacteriolytic.

Removal experiments of pathogenic human viruses were performed by batch method under aseptic conditions using $50 \mathrm{~g} \mathrm{~L}^{-1}$ of cross-linked PBVP(Br) at $35^{\circ} \mathrm{C}$. Levels of infectivity in suspensions of enterovirus, herpes simplex virus, poliovirus, and human immunodeficiency virus were reduced 1,000-1,000,000 fold during $2 \mathrm{~h}$. Those of coxsackievirus and echovirus were reduced 60-600 fold during $1 \mathrm{~h}$. The haemagglutinaion titres of solutions of human rotavirus, influenza virus, human adenovirus, and Japanese encephalitis virus were reduced 16-256 fold during $30 \mathrm{~min}$.

This epoch-making and serendipitous discovery was brought around by a fresh and eccentric idea of my inexperienced student. General water disinfection processes involve removal and destruction of micro-organisms and viruses by both physical and chemical means. A serious defect of chemical disinfection is the formation of harmful chemical materials accompanied with the chemical treatment. We attempted to develop an efficient physical method using insoluble and functional polymer in order to prevent leaving of harmful chemical materials in the treated water. 


\subsubsection{Inducement to attempt removal of bacteria from water with use of cross-linked PBVP(Br)}

My research group accidentally discovered an eccentric ion-exchange reaction of cross-linked PBVP(Br) that showed prior adsorption of organic pollutants that contained $-\mathrm{SO}_{3} \mathrm{Na}$, such as surface active agents and dyestuffs, over inorganic salts [5].

Since ion-exchange resins were used to remove microbes from water [6], we attempted to remove bacteria from water using cross-linked PBVP(Br) and discovered much stronger removal of bacteria than conventional ion-exchange resins [2]. After removal experiment, we accidentally stored used polymer in desiccator without sterilization. After several days, we were shocked by violent proliferation of bacteria on the polymer surface, which was covered by proliferated bacteria that resembled a group of breeding mold. We recognized that bacteria were strongly captured on the polymer surface in the living state. However, we overlooked considerably strong biodegradability of cross-linked $\operatorname{PBVP}(\mathrm{Br})$, in spite of the fact that there were no organic materials other than the polymer and the bacteria.

\subsubsection{Influence of chemical structure of cross-linked PBVP(Br) on the ability to capture bacterial cells}

Effect of chemical structure of cross-linked PBVP(Br) on the ability to capture bacterial cells in water was investigated by equilibrium capture experiment [7]. Strong ability of the polymer to capture bacterial cells was further confirmed by these experiments. The ability was quantitatively evaluated by removal coefficient based on the initial rate of decrease of viable cell counts caused by the addition of the polymer to bacterial suspension. The removal coefficient of cross-linked PBVP(Br) was extraordinarily larger than those of many other synthetic polymers examined. The removal coefficient uniformly increased with the content of $\mathrm{BVP}(\mathrm{Br})$, and indicated that the presence of $\mathrm{BVP}(\mathrm{Br})$ is definitively important in the capture of bacterial cells by crosslinked PBVP(Br).

The removal coefficient considerably increased when the content of divinylbenzene became smaller. This result indicated that high degree of swelling in water of the polymer matrix of cross-linked PBVP(Br) enhanced the ability to capture bacterial cells. This result indicated important contribution of water in the capture of bacterial cells by cross-linked PBVP(Br). The removal coefficient increased with content of 4-vinylpyridine in the polymer matrix of cross-linked PBVP(Br), and indicated that hydrophilicity of polymer matrix of cross-linked PBVP(Br) enhanced the ability to capture bacterial cells in water.

Hydrophilicity and high degree of swelling in water of the polymer matrix of cross-linked PBVP(Br) appeared to enhance the ability to capture bacterial cells, as well as the biodegradability of the polymer. 


\subsubsection{Affinity of bacterial cells with cross-linked PBVP(Br)}

The capturing interaction between cross-linked PBVP(Br) and bacterial cells was investigated in detail. Strength of the capturing interaction was evaluated by the removal coefficient based on the initial rate of decrease of viable cell counts caused by the presence of cross-linked PBVP(Br). Hydrophobic bacteria and hydrophilic bacteria showed distinct differences in the capturing interaction [8]. With hydrophobic bacteria such as S.aureus and S. typhimurium, electrostatic interaction and hydrophobic interaction between polymer surface and bacterial cells appeared to be important in the affinity of cross-linked PBVP(Br) with bacteria. With hydrophilic bacteria such as E. coli, Enterobacter sp. and Klebsiella sp., however, other factors such as solvent (water) mediated forces and hydrodynamic forces appeared significant.

\subsubsection{Bioreactor using bacterial cells immobilized by capture on the surface of cross-linked PBVP(Br)}

We developed a new type of bioreactor using bacterial cells immobilized by capture on the surface of cross-linked PBVP(Br) [9]. Whole cells of E. coli with aspartase activity were captured on the polymer surface. When suspension of the bacterial cells in buffer solution was passed through a glass column containing beads of cross-linked PBVP(Br), bacterial cells were captured on the polymer surface and formed an immobilized cell system. A fixed-bed column reactor containing $300 \mathrm{mg}$ of the bacterial cells immobilized by capture on $10 \mathrm{~g}$ of the polymer beads was used for the preparation of $\mathrm{L}^{-}$ aspartic acid from ammonium fumarate. Continuous operation of the bioreactor produced L-aspartic acid in a quantitative yield.

Entrapment of biocatalysts inside a polymer network or capsule is the most commonly used method for immobilization of microbial cells. In this case, however, the transport of a substrate or product of high molecular weight compounds into and out of the polymer matrix is hindered. This disadvantage can be avoided by use of the new method of immobilization, i.e., capture of microbial cells on the surface of cross-linked PBVP(Br).

\subsubsection{Removal of bacteria and virus by filtration through composite microporous membrane made of cross-linked PBVP(Cl)}

Conventional treatment processes for water supplies have been thought to inactivate viruses adequately, but detection of infectious human viruses in treated drinking water has raised concern that the processes may not always inactivate viruses [10]. Viruses are reported to be more resistant than bacteria to chlorine disinfection [11]. Therefore, development of effective method to remove viruses from drinking water is of special importance in the field of public health and hygiene. We developed microporous filter materials for removal of virus from water by using copolymer of styrene with BVP(Cl), PST- 
$c o-\mathrm{BVP}(\mathrm{Cl})$, in molar ratio of $5: 2$ [12]. Ultrafiltration using one to three sheets of $145 \mu \mathrm{m}$-thick cellulose nitrate membrane with pore size $0.45 \mu \mathrm{m}$ and coated with $1.7 \mathrm{mg} \mathrm{g}^{-1}$ of PST-co-BVP(Cl) showed 99.4-99.998\% removal of bacteriophage $\mathrm{T} 4$, whereas control experiments using not coated membrane showed 91-95\% removal of bacteriophage T4. Composite $360 \mu \mathrm{m}$-thick microporous membrane with pore size of $20 \mu \mathrm{m}$ was prepared that consisted of connected minute beads of $1.7 \mu \mathrm{m}$ diameter made of cross-linked PBVP(Br) and reinforced by unwoven cloth. Simple filtration using one sheet of the composite membrane at $34.2 \mathrm{~cm} \mathrm{~h}^{-1}$ showed $99.96-99.9995 \%$ removal of bacteriophage T4. The virus was not detected in the filtrate when two sheets of the composite membrane were used.

Virus was effectively removed by filtration from air with use of the composite microporous membrane [13]. We used a $0.83 \mathrm{~mm}$-thick membrane with pore diameter $14.3 \mu \mathrm{m}$ and porosity $42 \%$ consisted of connected minute beads of $1.7 \mu \mathrm{m}$ diameter made of cross-linked PBVP(Cl) and reinforced by unwoven cloth. Filtration using one sheet of the membrane removed 99.9994-99.9998 \% of bacteriophage T4 from air, in spite of the fact that pore size of the membrane was greatly larger than the virus.

The composite microporous membrane made of cross-linked PBVP(Cl) effectively removed bacteria from air by filtration [14]. Thickness, pore diameter and porosity of the membrane were $0.72 \mathrm{~mm}, 14.5 \mu \mathrm{m}$ and $63 \%$, respectively. Diameter of connected minute beads was $1.4 \mu \mathrm{m}$. Filtration at $63.7 \mathrm{~cm} \mathrm{sec}^{-1}$ gave $99.98 \%$ and $99.996 \%$ removal of E. coli and P. aeruginosa, respectively. S. aureus was not detected in the filtrate. 


\subsection{STRONG ACTION OF LINEAR POLY( $N$-BENZYL-4- VINYLPYRIDINIUM HALIDE) UPON MICROBIAL CELLS}

It should be noticed that linear (not-cross-linked) $\mathrm{PBVP}(\mathrm{Br}$ ) exhibits quite different properties from that of cross-lined PBVP(Br) based on the strong affinity of the pyridinium group with microbial cells and virus. Cross-linked PBVP(Br) and PBVP(Cl) capture bacterial cells in the living state. In contrast, linear $\mathrm{PBVP}(\mathrm{Br})$ and $\mathrm{PBVP}(\mathrm{Cl})$ exhibit strong bactericidal activity. In addition, linear $\mathrm{PBVP}(\mathrm{Br})$ and $\mathrm{PBVP}(\mathrm{Cl})$ facilitates coagulation and sedimentation of microbial cells suspended in water.

\subsubsection{Strong antibacterial activity of linear $P B V P(B r)$}

Cross-linked PBVP(Br) is insoluble in water and powerfully captures bacterial cells in the living state [2]. On the contrary, however, linear $\mathrm{PBVP}(\mathrm{Br})$ is soluble in water and hygroscopic, and shows a very strong bactericidal activity [15]. Linear PBVP(Br) showed strong antibacterial activity against Grampositive bacteria such as Arthrobacter atrocyaneus, Bacillus subtilis, S. aureus and Streptococcus sp., but showed fairly less activities against Gram-negative bacteria such as E.coli, Klebsiella pneumoniae, P. aeruginosa, S. typhimurium, and Serratia marcescens. The antibacterial activity of this polymer was considerably greater than that of the corresponding monomeric compound, and a notable polymer effect was suggested. Bactericidal activity of linear $\mathrm{PBVP}(\mathrm{Br})$ was a match for conventional disinfectants such as benzalkonium chloride and chlorohexidine. However, it should be strongly noticed that copolymers of vinyl compounds with BVP does not exhibit bactericidal activity in the case where the content of BVP is low.

\subsubsection{Removal of bacteria from water by coagulation and sedimentation using linear $\mathrm{PBVP}(\mathrm{Br})$ and $\mathrm{PBVP}(\mathrm{Cl})$ and their copolymers}

Linear PBVP(Br) shows an eccentric property against bacteria in addition to strong bactericidal activity, and produced coagulation and sedimentation of bacterial cells [16]. Addition of $5 \mathrm{mg} \mathrm{L}^{-1}$ of linear PBVP(Br) to suspensions of bacterial cells was sufficient, and turbidity resulted by suspended solids was not necessary for the coagulation. Linear PBVP(Br) easily produced coagulation of Gram-positive bacteria, Gram-negative bacteria and yeast, with some exceptions such as Streprococcus sp., P. aeruginosa and S. cerevisie. The corresponding monomeric compound did not produce any coagulation, and suggested a notable polymer effect in the coagulation and sedimentation by linear PBVP(Br).

Coagulation and sedimentation of bacteria was not limited to linear PBVP(Cl) and PBVP(Br). Copolymer of acrylamide with 11.0 mole \% of BVP(Cl), PAAM $_{8^{-}}$ 
co-BVP $(\mathrm{Cl})_{1}$, produced coagulation and sedimentation of E.coli, B. subtillus, P. aeruginosa, and S. aureus [17]. Addition of more than $50 \mathrm{mg} \mathrm{L}^{-1}$ of $\mathrm{PAAM}_{8}-\mathrm{Co}-$ $\mathrm{BVP}(\mathrm{Cl})_{1}$ produced bacterial flocks that precipitated at a rate of around $200 \mathrm{~cm} \mathrm{~h}^{-1}$. Reduction of supernatant population of bacteria was in the range of $1 / 30,000$ to $1 / 25,000,000$. PAAM $_{8}-\mathrm{Co}-\mathrm{BVP}(\mathrm{Cl})_{1}$ was highly biodegradable. Details of the biodegradability of $\mathrm{PAAM}_{8}-\mathrm{Co}-\mathrm{BVP}(\mathrm{Cl})_{1}$ are explained later.

Coagulation and sedimentation of Ralstonia solanacearum was also realized by addition of linear copolymer of methyl methacrylate with $\mathrm{BVP}(\mathrm{Cl})$ in molar ratio of $3: 1, \mathrm{PMMA}_{3}-\mathrm{Co}-\mathrm{BVP}(\mathrm{Cl})_{1}$ [18]. The coagulation appeared to be accomplished within $1 \mathrm{~h}$ when $200 \mathrm{mg} \mathrm{L}^{-1}$ of $\mathrm{PMMA}_{3}-\mathrm{Co}-\mathrm{BVP}(\mathrm{Cl})_{1}$ was added.

Coagulation and sedimentation of bacterial cells was also realized by addition of sawdust that was coated with 1 weight \% of equimolar copolymer of styrene with BVP(Cl) [19]. When the coated sawdust was mixed with suspension of E. coli and allowed to stand, the coated sawdust precipitated and the bacterial cells formed flocks and accumulated over the precipitated sawdust, and bacterial population in the supernatant layer reduced to $1 / 1,000,000$ or less during the procedure under appropriate conditions.

\subsubsection{Removal of micro-organisms by filtration through unwoven cloth coated with copolymer of styrene with BVP(Cl)}

Unwoven cloth coated with $32 \mathrm{mg} \mathrm{g}^{-1}$ of an equimolar copolymer of styrene with $\mathrm{BVP}(\mathrm{Cl}), \mathrm{PST}_{1}-\mathrm{Co}-\mathrm{BVP}(\mathrm{Cl})_{1}$ was found to be effective in the removal of micro-organisms from water [20]. In the removal of $E$. coli from water (influent concentration was $8.34 \times 10^{6}$ cells $\mathrm{mL}^{-1}$ ) by filtration through ten sheets of the coated unwoven cloth, rate of removal was $99.99 \%$ at filtration rate of $2.6 \mathrm{~cm} \mathrm{~h}^{-1}$, and remained $99 \%$ even at high filtration rate of $300 \mathrm{~cm} \mathrm{~h}^{-1}$ and low influent concentration of bacterial cells such as $10^{3}$ cells $\mathrm{mL}^{-1}$. The rate of removal tended to increase with decrease of influent bacterial concentration. Seven other bacteria and two yeasts were effectively removed by filtration through the coated unwoven cloth. Filtration through the coated unwoven cloth was also effective in the removal of spores of fungi from water, but was not very effective in the removal of bacteriophage $\mathrm{T} 4$ from aqueous suspension.

\subsubsection{Electrochemical sensor for viable microbial cell concentration using copolymer of styrene with BVP(Cl)}

Conventional measurement of concentration of viable microbial cells suspended in water is based on colony counts. This method requires at least $24 \mathrm{~h}$. We developed a new and convenient method for rapidly measuring the concentration of viable aerobic and facultatively anaerobic microbial cells suspended in water [21].

The sensor was consisted of a flow cell that contained an oxygen electrode and unwoven cloth coated with $10 \mathrm{mg} \mathrm{g}^{-1}$ of a copolymer of styrene with BVP(Cl) 
that contained 27 mole $\%$ of $\mathrm{BVP}(\mathrm{Cl}), \mathrm{PST}_{3}-\mathrm{Co}-\mathrm{BVP}(\mathrm{Cl})_{1}$. When a sample suspension of microbial cells is passed through the electrochemical sensor at a constant flow rate, the microbial cells are captured on the surface of the coated unwoven cloth in the living state, and accumulated. The consumption of oxygen by the captured living microbial cells appears as a decrease in the electric current. Rate of decrease of the electric current is proportional to the concentration of viable microbial cells. A control experiment was performed using suspension of bacterial cells killed by autoclaving. In this case, a negligible decrease in the electric current was observed. Each measurement required about $10 \mathrm{~min}$. The minimum detectable concentration of living microbial cells expressed at $610 \mathrm{~nm}$ was $0.005-0.023$. The minimum detectable concentration of bacterial cells in colony count was $3.7 \times 10^{5}$ cells $\mathrm{mL}^{-1}$ in the case of $E$. coli.

\subsubsection{Bioreactor using bacterial cells immobilized on the surface of unwoven cloth coated with copolymer of styrene with BVP(Cl)}

Cells of Arthrobacter simplex having 3-ketosteroid- $\Delta^{1}$-dehydro-monogenase activity were immobilized by capture on the surface of unwoven cloth coated with a copolymer of styrene with 25 mole \% of BVP(Cl), $\mathrm{PST}_{3}-\mathrm{Co}-\mathrm{BVP}(\mathrm{Cl})_{1}$ [22]. The captured bacterial cells catalyzed dehydrogenation of cortisol to prednisolone in solvents containing methanol. A fixed-bed column reactor was continuously operated, and yielded about $90 \%$ of prednisolone during 6 days.

Cells of E. coli having aspartase activity were immobilized by capture on the surface of unwoven cloth coated with copolymer of styrene with 29 mole $\%$ of $\mathrm{BVP}(\mathrm{Cl}), \mathrm{PST}_{2}-\mathrm{Co}-\mathrm{BVP}(\mathrm{Cl})_{1}$ [23]. Continuous operation of a fixed-bed column reactor containing the immobilized cells produced L-aspartic acid in $95 \%$ yield from ammonium fumarate. Stability of the enzymatic activity of the immobilized cells was much improved by use of the coated unwoven cloth as the supporting material instead of beads of cross-linked PBVP(Cl).

\subsubsection{Control of soil-borne plant diseases by capture of disease germs using sawdust coated with copolymer of styrene with BVP(Cl)}

Control of soil-borne diseases of plants is a significant subject in agriculture. Conventional treatment processes involve disinfection using chemical materials as fungicides. However, use of hazardous chemical materials is not desirable for protection of environment. In addition, international treaty decided on prohibition of the use of methyl bromide for fumigation because of its property of destroying the ozone layer. Under the social circumstances, an alternative method for effective protection of plants from soil-borne diseases is eagerly anticipated, and biological control and other non-chemical methods 
have received increasing attention. Furthermore, use of poorly biodegradable chemical materials as disinfectants is not desirable, because they remain in soil for a long time, and induce disease germs to obtain resistance power against the disinfectants.

My research group accidentally discovered cure of a soil-borne disease of fruit tree when we wrapped roots of the tree in unwoven cloth coated with equimolar copolymer of styrene with BVP(Cl). Although we tried the treatment only one time, the fruit tree did not exhibit the symptom after the treatment. Since the discovered cure of the soil-borne disease of fruit tree was heterogeneous, we expected to develop a novel method for the control of soilborne plant diseases.

Tomato bacterial wilt caused by Ralstonia solanacearum was controlled by the addition of sawdust coated with 1 weight $\%$ of equimolar copolymer of styrene with BVP $(\mathrm{Cl}), \mathrm{PST}_{1}-\mathrm{Co}-\mathrm{BVP}(\mathrm{Cl})_{1}$, prior to transplantation $[24,25]$. This method effected $87 \%$ reduction in appearance and $89 \%$ reduction in the index of symptom under appropriate conditions. The coated sawdust did not exhibit bactericidal activity against $R$. solanacearum. Half-life of the polymer was only 5.6 days when treated with activated sludge in soil, and remaining possibility in soil is expected to be very low. The disease control by the coated sawdust was explained in terms of reduction of infectious contact between the roots of tomato and the cells of $R$. solanacearum due to coagulation-like interaction between microbial cells and the coated sawdust, in addition to capture of the disease microbial cells by the coated sawdust.

\subsubsection{Suppression of soil-borne plant disease by coagulation of disease germs using copolymer of methyl methacrylate with BVP(Cl)}

We attempted to develop another new technology to control soil-borne plant diseases without disinfection of disease germs, and realized suppression of tomato bacterial wilt caused by R. solanacearum by coagulation of cells of disease germs with use of copolymer of methyl methacrylate with BVP(Cl) in molar ratio of $3: 1, \mathrm{PMMA}_{3}-\mathrm{Co}-\mathrm{BVP}(\mathrm{Cl})_{1}$, as polymeric coagulant for microbial cells [18]. When $10 \mathrm{mg} \mathrm{kg}^{-1}$ of the above copolymer was added to soil before transplanting of seedlings of tomato, and $2 \mathrm{mg} \mathrm{kg}^{-1}$ of the copolymer was supplemented once a week after transplanting, $51 \%$ reduction of appearance and $54 \%$ reduction of index of symptoms were observed. $\mathrm{PMMA}_{3}-\mathrm{Co}-\mathrm{BVP}(\mathrm{Cl})_{1}$ did not exhibit bactericidal activity against $R$. solanacearum, and it appeared that coagulation of the bacterial cells reduced the opportunity for infectious contact of roots of tomato with cells of $R$. solanacearum, and resulted in the disease suppression. $\mathrm{PMMA}_{3}-\mathrm{Co}-\mathrm{BVP}(\mathrm{Cl})_{1}$ was shown to be highly biodegradable, and the half-life was 5.1 days when treated with activated sludge in soil. 


\subsection{VIOLENT DIGESTION OF CROSS-LINKED PBVP(Br) BY ACTIVATED SLUDGE}

\subsubsection{Miserably complete failure of using cross-linked PBVP(Br) as a filter medium for bio-film process of sewage treatment}

The starting point of our research work with respect to exertion of strong biodegradability to vinyl polymers by insertion of BVP into the main chain is our accidental discovery of powerful capture of bacteria in the living state and proliferation of bacteria on the surface of cross-linked PBVP(Br) [2]. At that time, we were drawn to investigate mechanism of the capturing phenomenon and utilities of vinyl polymers that contained BVP in the main chain, and overlooked the great importance of proliferation of bacteria on the surface of the polymer. Proliferation of bacteria on the surface of the polymer is an important evidence of vigorous consumption of the polymer by bacteria, and exceptionally strong biodegradability of the polymer. After about ten years, we were greatly shocked by violent digestion of the polymer by activated sludge [26].

As an extension of investigation on utility of capture of bacteria on surface of cross-linked PBVP(Br), we attempted to use this polymer as filter medium for bio-film process of aerobic treatment of sewage [27-29]. We performed continuous aerobic treatment of artificial sewage by activated sludge using a test apparatus filled with cross-linked PBVP(Br) prepared in the form of Raschig ring. Time course of the chemical oxygen demand (COD) of the effluent solution during the biological treatment is shown in Figure 2 [26]. We expected removal of COD by continuous aerobic treatment of artificial sewage by activated sludge. Contrary to this expectation, however, COD of effluent solution was extraordinarily larger than that of influent sewage during early 2-3 weeks of the treatment, as shown in Figure 2. This unbelievable increase of COD during the biological treatment was attributed to the presence of crosslinked $\mathrm{PBVP}(\mathrm{Br})$, because there was no organic materials existed in the treatment system other than the organic components of artificial sewage and activated sludge. Since cross-linked PBVP(Br) used in the experiment was insoluble in water, increase of COD during the aerobic treatment was explained in terms of increase of microbial cell population in the treatment system. In other words, increase of COD was explained in terms of proliferation of microbial cells contained in activated sludge due to digestion of cross-linked $\mathrm{PBVP}(\mathrm{Br})$ as their favorite dish. Cross-linked PBVP(Br) was found to be strongly favorited by microbes contained in activated sludge. 


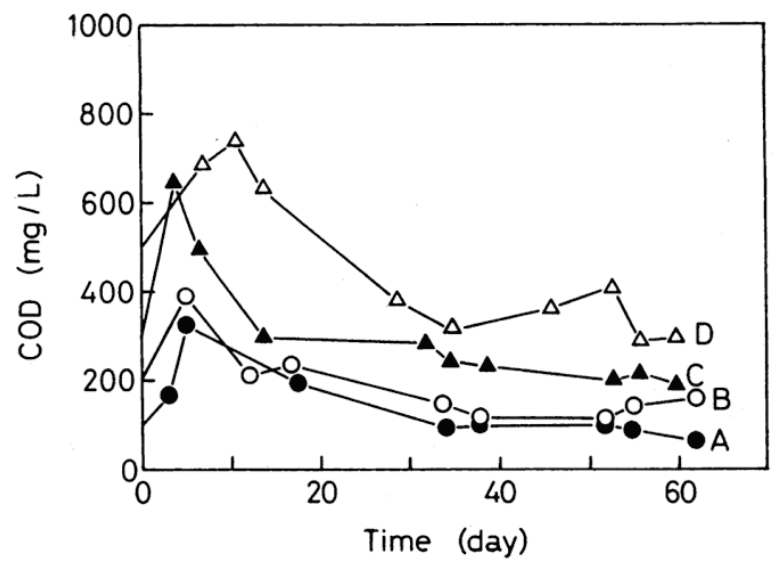

Figure 2. Course of COD in continuous aerobic treatment of artificial sewage by activated sludge in the presence of cross-linked PBVP(Br) prepared in the form of Raschig ring. Influent COD (mg L-1): A - 100; B - 200; C - 300; D - 500.

Since we conjectured digestion of cross-linked PBVP(Br) by activated sludge during the treatment, we pursued gravimetric weight of the polymer during the treatment. After a prescribed time, polymer samples were taken out from the treatment system, washed with deionized water, and dried to constant weight. Dry weight of cross-linked PBVP(Br) conspicuously decreased during the biological treatment as shown in Figure 3. Weight reduction of cross-linked PBVP(Br) during the treatment would be an evidence of digestion of the polymer by activated sludge. Extent of weight reduction was obviously increased with substrate load of influent artificial sewage. This result suggested that digestion of cross-linked PBVP(Br) by activated sludge was accompanied by digestion of organic substrates contained in influent artificial sewage. 


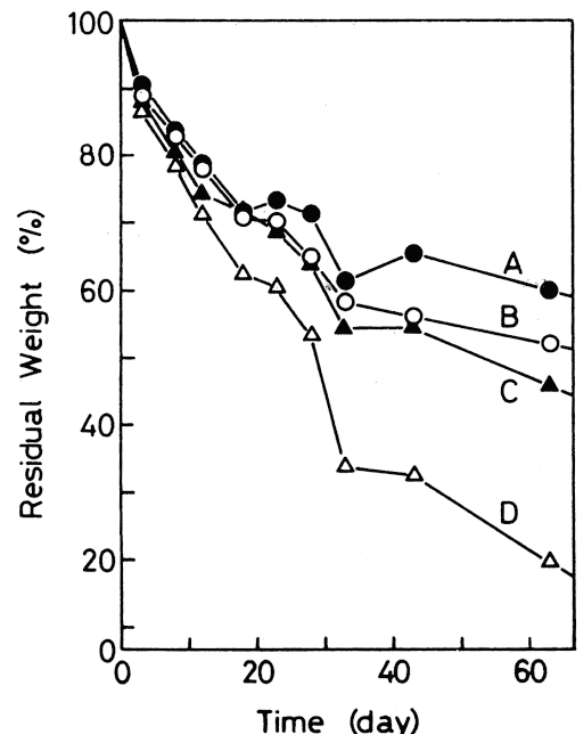

Figure 3. Change of weight of cross-linked PBVP(Br) prepared in the form of Raschig ring in continuous aerobic treatment of artificial sewage by activated sludge in the presence of the polymer. Influent COD $\left(\mathrm{mg} \mathrm{L}^{-1}\right)$ : A - 100; B - 200; C - 300; D - 500 .

This accidental discovery is a severely negative result in the development of new chemical material useful for bio-film process. Considerable increase of COD of artificial sewage during the aerobic treatment with activated sludge is a desperately opposite result of our original expectation. In contrast, however, surprisingly violent digestion of synthetic polymer by activated sludge is an exciting and dreamlike discovery that gives us promising expectation of breakthrough methodology for complete transfiguration of poorly biodegradable synthetic polymers to strongly biodegradable synthetic polymers. We assumed that digestion of cross-linked PBVP(Br) by activated sludge was attributed, at least partly, to the presence of $\mathrm{BVP}(\mathrm{Br})$ in the main chain of the polymer. Therefore, we attempted exertion of strong biodegradability to synthetic high molecular weight vinyl polymer with exclusive carbon-carbon bonds in the main chain by insertion of BVP(Br) or $\mathrm{BVP}(\mathrm{Cl})$ into the main chain.

\subsubsection{Essence of biodegradability of polymers that harmonized with recycling system of materials in the natural environment}

I keenly realized the great importance of nutritive worth for microbes in charge of biodegradation in synthesis of biodegradable polymers. In abundant natural environment, harmonious recycling system of materials fulfils its function, and there is no useless waste in the harmonious recycling system. 
Essence of biodegradability seems to be keeping of harmony with this natural recycling system.

\subsection{BIODEGRABILITY OF POLY(METHYL METHACRYLATE) (PMMA) THAT CONTAINS BVP(Cl) IN THE MAIN CHAIN}

Connection of oligomers of vinyl compounds by biodegradable chemical unit is an effective method in the syntheses of biodegradable vinyl polymers, because oligomers of vinyl compounds are biodegradable unlike the corresponding high molecular weight vinyl polymers [30]. For example, biodegradable poly(carboxylic acid) was prepared by incorporation of vinyl alcohol into the main chain [31]. Therefore, we attempted to use BVP(Cl) as a biodegradable chemical unit to connect oligomers of vinyl compounds in synthesis of biodegradable vinyl polymers, and investigated biodegradation of copolymers of methyl methacrylate with $\mathrm{BVP}(\mathrm{Cl}), \mathrm{PMMA}-\mathrm{co}-\mathrm{BVP}(\mathrm{Cl})$, by activated sludge [26].

Polymer samples were prepared as films of $3 \mathrm{~cm}$ wide, $3 \mathrm{~cm}$ length, and $0.13 \mathrm{~mm}$ thick. The polymer films were placed in a cage made of 8-mesh saran net, and the cage was placed in an aeration tank of a sewage works by hanging with a rope. Before the biological treatment, intrinsic viscosity determined in chloroform at $30^{\circ} \mathrm{C}$ was in the range of $0.41-0.55 \mathrm{dL} \mathrm{g}^{-1}$.

In Figure 4 is plotted the ratio of intrinsic viscosity of the recovered polymer sample to that before the biological treatment versus the treatment time. In the case of homo-polymer of methyl methacrylate (Figure 4A), change of molecular weight was not significant and clearly indicates that homo-polymer of methyl methacrylate is not biodegradable. When the content of BVP(Cl) was 1 mole \% (Figure 4B), reduction of molecular weight of PMMA-co-BVP(Cl) was negligible. On the other hand, reduction of molecular weight was significant when the content of $\mathrm{BVP}(\mathrm{Cl})$ was 5 mole \% (Figure $4 \mathrm{C}$ ) and 10 mole \% (Figure 4D).

However, reduction of molecular weight appeared to reach the uppermost limit after about 30 days of the biological treatment. These results clearly indicate that biodegradability of the $\mathrm{BVP}(\mathrm{Cl})$ portion is overwhelmingly stronger than that of the oligomer portion. 


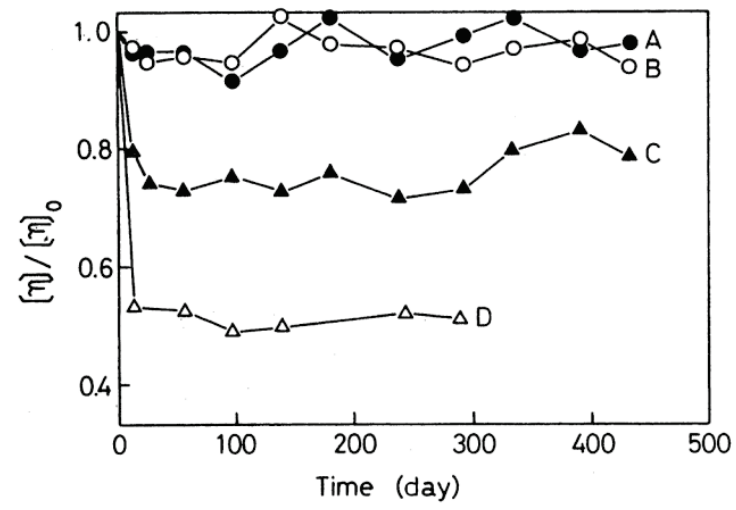

Figure 4. Ratio of intrinsic viscosity of PMMA-co-BVP(Cl) recovered after placing in an aeration tank of sewage works to that before the biological treatment. Intrinsic viscosity of the polymer determined in chloroform at $30^{\circ} \mathrm{C}$ before the biological treatment $\left(\mathrm{dL} \mathrm{g}^{-1}\right): \mathrm{A}-0.54 ; \mathrm{B}-0.41 ; \mathrm{C}-0.50$; D - 0.55. Contents of BVP $(\mathrm{Cl})($ mole $\%)$ : $\mathrm{A}-0 ; \mathrm{B}-1 ; \mathrm{C}-5 ; \mathrm{D}-10$.

Figure 5 shows weight reduction of PMMA-co-BVP(Cl) during the biological treatment. Although the data fluctuated widely, weight of polymer samples reduced during the biological treatment. It should be noticed that weight reduction of $\mathrm{PMMA}-\mathrm{Co}-\mathrm{BVP}(\mathrm{Cl})$ did not reach the uppermost limit and continued during the biological treatment. This result clearly indicates that biodegradation of oligomer portion of PMMA-co-BVP(Cl) continued during the treatment, making a sharp contrast to the case of homo-polymer of methyl methacrylate.

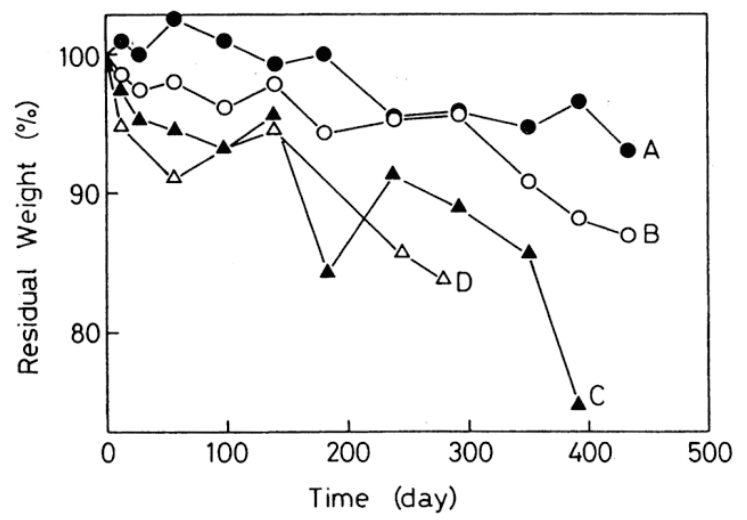

Figure 5. Weight reduction of PMMA-co-BVP(Cl) during placing in an aeration tank of sewage works. Intrinsic viscosity of the polymer determined in chloroform at $30^{\circ} \mathrm{C}$ before the biological treatment $\left(\mathrm{dL} \mathrm{g}^{-1}\right)$ : A $-0.54 ; \mathrm{B}-0.41 ; \mathrm{C}-0.50$; $\mathrm{D}-0.55$. Contents of BVP(Cl) (mole \%): A - 0; B - 1; C - 5; D - 10. 
We further investigated biodegradation of copolymer of methyl methacrylate with 24.3 mole $\%$ of $\mathrm{BVP}(\mathrm{Cl}), \mathrm{PMMA}_{3}-\mathrm{Co}-\mathrm{BVP}(\mathrm{Cl})_{1}$, by activated sludge in soil [18]. Test soil was washed with water using a Soxhlet extraction apparatus for $30 \mathrm{~h}$, and the washed soil was further purified by Soxhlet extraction using a mixed solvent of toluene with ethanol in a volume ratio of $7: 3$ to remove organic materials included in the test soil, and dried to constant weight under reduced pressure. The test soil was sterilized by autoclaving at $121^{\circ} \mathrm{C}$ for $180 \mathrm{~min}$. After 2 days, the autoclaving was repeated once again just before the biological degradation of $\mathrm{PMMA}_{3}-\mathrm{Co}-\mathrm{BVP}(\mathrm{Cl})_{1}$. Polymer sample $(100 \mathrm{mg})$ was dissolved in a mixed solvent $(10 \mathrm{~mL})$ of toluene and ethanol in a volume ratio of $7: 3$, and the polymer solution was mixed with the purified soil $(50 \mathrm{~g})$. Thus, content of the polymer sample in the dried soil was $2.0 \mathrm{~g} \mathrm{~kg}^{-1}$. This mixture was then placed in a desiccator, and the solvents were removed by drying under reduced pressure to constant weight. Activated sludge was obtained from sewage works immediately before the biological degradation, and washed three times with sterilized physiological saline.

In this study, we prepared artificial sewage according to a literature recipe [28], and used to assist the biological degradation of polymer samples. Peptone $(6.0 \mathrm{~g})$, meat extract $(4.0 \mathrm{~g})$, urea $(1.0 \mathrm{~g})$, sodium chloride $(0.30 \mathrm{~g})$, potassium chloride $(0.14 \mathrm{~g})$, calcium chloride $(0.14 \mathrm{~g})$, magnesium sulfate $(0.10 \mathrm{~g})$, and disodium hydrogen-phosphate $(1.0 \mathrm{~g})$ were dissolved in $1,000 \mathrm{~mL}$ of distilled water, and $\mathrm{pH}$ was adjusted to 8.5. COD of this undiluted solution was about $10,000 \mathrm{mg} \mathrm{L}^{-1}$. This solution was diluted with an appropriate amount of distilled water to prepare artificial sewage of prescribed COD concentration.

Washed activated sludge $(710 \mathrm{mg}$ in the wet weight that corresponded to $50 \mathrm{mg}$ in the dry weight) and artificial sewage $(1.0 \mathrm{~mL}$ with a COD concentration of $\left.10,000 \mathrm{mg} \mathrm{L}^{-1}\right)$ were mixed with the test soil $(50 \mathrm{~g})$ that contained $100 \mathrm{mg}$ of the polymer sample. Since $1.0 \mathrm{~mL}$ of the added artificial sewage contained $10 \mathrm{mg}$ of COD, and weight of the polymer sample was $100 \mathrm{mg}$, the amount of organic materials in the artificial sewage added to $1 \mathrm{~g}$ of the polymer sample was $100 \mathrm{mg}$ as COD. The total amount of water added to the test soil was set to be $180 \mathrm{~g} \mathrm{~kg}^{-1}$. The mixture was allowed to stand at room temperature.

After a prescribed time, the remaining polymer sample was recovered by Soxhlet extraction using a mixed solvent of toluene with ethanol in a volume ratio of $7: 3$ for $30 \mathrm{~h}$. Fine soil particles contained in the extractive was removed by centrifugation three times at 2,000 g. The supernatant was placed in a rotary evaporator, and the mixed solvents were removed by evaporation. Ethyl acetate was added to the residue, and the recovered polymer was precipitated. The precipitated polymer was isolated and dried to constant weight under reduced pressure.

Figure 6 shows time course of weight reduction during the biological treatment by activated sludge in soil. In control experiments carried out in the 
absence of activated sludge, polymer sample was quantitatively recovered from test soil. Time course of weight reduction shown in Figure 6 followed first-order kinetics, and the half-life of $\mathrm{PMMA}_{3}-\mathrm{Co}$ - $\mathrm{BVP}(\mathrm{Cl})_{1}$ was evaluated to be 5.1 days under the experimental conditions. This half-life suggests that the amount of residual $\mathrm{PMMA}_{3}-\mathrm{Co}-\mathrm{BVP}(\mathrm{Cl})_{1}$ would be reduced to $1 / 1000$ within 2 months of the biological treatment. Although biodegradation of $\mathrm{PMMA}_{3}-\mathrm{CO}$ $\mathrm{BVP}(\mathrm{Cl})_{1}$ in the natural environment may require a much more prolonged period, it is not necessary to afraid of severe persistency of $\mathrm{PMMA}_{3}-\mathrm{Co}-\mathrm{BVP}(\mathrm{Cl})_{1}$ in the natural environment. In contrast, homo-polymer of methyl methacrylate did not exhibit biodegradability under the conditions.

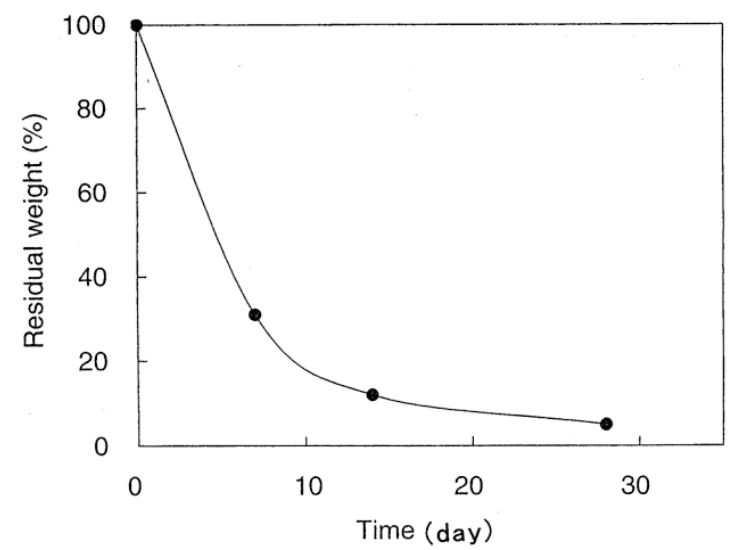

Figure 6. Time course of weight reduction of $\mathrm{PMMA}_{3}-\mathrm{Co}-\mathrm{BVP}(\mathrm{Cl})_{1}$ that contained 24.3 mole \% of BVP(Cl) during biological treatment with activated sludge in soil at room temperature. Amount of $\mathrm{PMMA}_{3}-\mathrm{Co}-\mathrm{BVP}(\mathrm{Cl})_{1}, 2.0 \mathrm{~g} \mathrm{~kg}^{-1}$; amount of activated sludge, $14.2 \mathrm{~g} \mathrm{~kg}^{-1}$ in wet weight ( $1.0 \mathrm{~g} \mathrm{~kg}^{-1}$ in dry weight); amount of artificial sewage used to assist the biodegradation, $0.2 \mathrm{~g} \mathrm{~kg}^{-1}$ in COD; amount of water, $180 \mathrm{~g} \mathrm{~kg}^{-1}$.

\subsection{BIODEGRADABILITY OF POLY(VINYL ACETATE) THAT CONTAINS BVP(Cl) IN THE MAIN CHAIN}

We investigated biodegradation of copolymer of vinyl acetate with $\mathrm{BVP}(\mathrm{Cl})$, PVAC-co-BVP(Cl), by placing in aeration tank of sewage work [32]. Polymer samples were prepared as films of $2.5 \mathrm{~cm}$ wide, $3.5 \mathrm{~cm}$ long and $0.5 \mathrm{~mm}$ thick. The polymer films were placed in a cage made of 100-mesh nylon net, and the cage was placed in aeration tank of sewage work by hanging with rope. After prescribed time, polymer films were taken out from the aeration tank, washed with deionized water, dried to constant weight, and submitted for analyses. Aspect of biodegradation of PVAC- $\mathrm{Co}$ - $\mathrm{BVP}(\mathrm{Cl})$ was much different from that of PMMA-co-BVP(Cl). 
In the control experiment using a homo-polymer of vinyl acetate, change of intrinsic viscosity as well as that of gravimetric weight were not very significant even after 1072 days of the biological treatment. On the other hand, PVAC-co-BVP(Cl) that contained 3.9 mole \% of BVP(Cl) showed a significant reduction in gravimetric weight during the biological treatment. After 7 days of the treatment, recovered polymer showed a $32 \%$ reduction in gravimetric weight. Exertion of biodegradability by insertion of $\mathrm{BVP}(\mathrm{Cl})$ into the main chain is effective for poly(vinyl acetate). Unexpectedly, however, further weight reduction was not observed after this period of the treatment. Exertion of strong biodegradability to poly(vinyl acetate) by insertion of BVP(Cl) into the main chain ended at early period of the biological treatment.

Intrinsic viscosity of recovered polymer was larger than that before the biological treatment. This result indicates that biodegradation of lower molecular weight fractions contained in the polymer sample predominated over that of higher molecular weight fractions during the treatment. This phenomenon was not observed in the biodegradation of PMMA-co-BVP(Cl).

We found an important phenomenon during the above biodegradation of PVAC-co-BVP(Cl). Chlorine was predominantly removed from the polymer at early period of the treatment. For example, PVAC-co-BVP(Cl) that contained 3.9 mole $\%$ of $\mathrm{BVP}(\mathrm{Cl})$ involved $1.51 \%$ of chlorine before the biological treatment, but chlorine was not detected in the residual polymers recovered after 28 days of the biological treatment. The uppermost limit of weight reduction during the biological treatment could be attributed to the disappearance of $\mathrm{BVP}(\mathrm{Cl})$ in the residual polymer at early period of the biological treatment.

Although chlorine disappeared from PVAC- $c o-\mathrm{BVP}(\mathrm{Cl})$ at early period of the treatment, nitrogen remained in the residual polymer recovered after the treatment. For example, PVAC- $c o-B V P(C l)$ that contained 3.9 mole $\%$ of $\mathrm{BVP}(\mathrm{Cl})$ showed the presence of $0.84 \%$ nitrogen before the biological treatment, and a remainder of 0.33 and $0.68 \%$ of nitrogen after 28 and 713 days. Presence of nitrogen and absence of chlorine could suggest that pyridyl group was included in the residual polymer recovered after the biological treatment, and that the presence of pyridyl group is not helpful for the improvement of poor biodegradability of poly(vinyl acetate).

Contrary to the biodegradation of PVAC-co-BVP(Cl), weight reduction did not exhibit uppermost limit at early period of the treatment in biodegradations of copolymer of methyl methacrylate with BVP(Cl), PMMA-co-BVP(Cl) [26], copolymer of styrene with BVP(Cl), PST-co-BVP(Cl) [35], copolymer of acrylamide with $\mathrm{BVP}(\mathrm{Cl})$, PAAM-co-BVP(Cl) [17], and copolymer of acrylonitrile with BVP(Cl), PAN-co-BVP(Cl) [36]. 


\subsection{BIODEGRABILITY OF POLY(ACRYLAMIDE) THAT CONTAINS BVP(Cl) IN THE MAIN CHAIN}

Poly(vinyl alcohol) is well-known as water-soluble and biodegradable vinyl polymer [33], but copolymer of acrylamide with BVP(Cl), PAAM-co-BVP(Cl), was found to be water-soluble and exceedingly more biodegradable than poly(vinyl alcohol) [17].

We used PAAM-co-BVP(Cl) that contained 82.1 mole \% of acrylamide, 11.0 mole $\%$ of $\mathrm{BVP}(\mathrm{Cl})$, and 7.0 mole $\%$ of acrylic acid.

Ratio of biochemical oxygen demand (BOD) to total organic carbon (TOC) of aqueous solution is an index of biodegradability of chemical materials, because TOC reflects substantial concentration of organic materials and BOD is a measure of concentration of biodegradable materials in the sample solution. We found that $\mathrm{BOD}_{5} / \mathrm{TOC}$ of the above PAAM-co-BVP(Cl) was 0.607 , whereas that of a commercial product of poly(vinyl alcohol) (100\% hydrolyzed and average molecular weight was 14,000 ) was 0.033 . Used sample of PAAM-co$\mathrm{BVP}(\mathrm{Cl})$ was much more biodegradable than used sample of poly(vinyl alcohol), in spite of the fact that average molecular weight of the sample of PAAM-co-BVP $(\mathrm{Cl})$ was exceedingly higher.

In contrast, aqueous solution of homo-polymer of acrylamide, PAAM, did not consume oxygen, and $\mathrm{BOD}_{5} / \mathrm{TOC}$ was substantially zero. Exertion of biodegradability to vinyl polymers by insertion of BVP(Cl) into the main chain is unexpectedly powerful.

We performed degradation of the above PAAM-co-BVP(Cl) by the treatment with activated sludge in water using a $200 \mathrm{~mL}$ shaking flask at $25^{\circ} \mathrm{C}$. Initial amount of TOC was $38.0 \mathrm{mg} \mathrm{L}^{-1}$ that consisted of the above PAAM-co-BVP(Cl) (30.0 $\mathrm{mg} \mathrm{L}^{-1}$ ), artificial sewage [28] added to assist the biodegradation (1.2 $\left.\mathrm{mg} \mathrm{L}^{-1}\right)$, and activated sludge that performed the biodegradation (6.8 $\mathrm{mg} \mathrm{L}^{-1}$ ). After 7 days, TOC of the sample mixture reduced to $7.1 \mathrm{mg} \mathrm{L}^{-1}$. We pursued total amount of organic carbon contained in the test solution, and did not pursue the real amount of PAAM-co-BVP(Cl) contained in the solution. However, amount of TOC remained in the solution after 7 days of the treatment was nearly equal to that of the initial amount of TOC contained in the solution due to the added activated sludge. Experimental results of weight reduction during the biological treatment followed first-order kinetics, and suggested that half-life of the above PAAM-co-BVP(Cl) during the biological treatment is only 2.4 days. If this biodegradability of the above PAAM-co- $\mathrm{BVP}(\mathrm{Cl})$ is unnecessarily strong, this defect can be easily improved by necessary retrenchment of the content of $\mathrm{BVP}(\mathrm{Cl})$ in the PAAM-co-BVP(Cl). 


\subsection{BIODEGRABILITY OF POLYSTYRENE THAT CONTAINS BVP(Cl) IN THE MAIN CHAIN}

Preparation of biodegradable polystyrene by connection of oligomers of styrene with use of $\mathrm{BVP}(\mathrm{Cl})$ as the biodegradable chemical unit appeared difficult, because oligomers of styrene larger than trimer are poorly biodegradable, although dimer of styrene is biodegradable [34]. However, we did not give up and tried to connect oligomers of styrene using BVP(Cl), and found that $\mathrm{BVP}(\mathrm{Cl})$ is not only a biodegradable chemical unit useful to connect biodegradable oligomers, but also facilitates biodegradation of the connected oligomer portion [35].

We used six types of copolymers of styrene with $\mathrm{BVP}(\mathrm{Cl})$, i.e., equimolar copolymer of styrene with $\mathrm{BVP}(\mathrm{Cl}), \mathrm{PST}_{1}-\mathrm{Co}-\mathrm{BVP}(\mathrm{Cl})_{1}$, copolymer of styrene with $\mathrm{BVP}(\mathrm{Cl})$ in molar ratio of $2: 1, \mathrm{PST}_{2}-\mathrm{Co}-\mathrm{BVP}(\mathrm{Cl})_{1}$, copolymer of styrene with $\mathrm{BVP}(\mathrm{Cl})$ in molar ratio of $3: 1, \mathrm{PST}_{3}-\mathrm{Co}-\mathrm{BVP}(\mathrm{Cl})_{1}$, copolymer of styrene with $\mathrm{BVP}(\mathrm{Cl})$ in molar ratio of $4: 1, \mathrm{PST}_{4}-\mathrm{Co}-\mathrm{BVP}(\mathrm{Cl})_{1}$, copolymer of styrene with $\mathrm{BVP}(\mathrm{Cl})$ in molar ratio of $5: 1, \mathrm{PST}_{5}-\mathrm{Co}-\mathrm{BVP}(\mathrm{Cl})_{1}$, and copolymer of styrene with $\mathrm{BVP}(\mathrm{Cl})$ in molar ratio of $8: 1, \mathrm{PST}_{8}-\mathrm{Co}-\mathrm{BVP}(\mathrm{Cl})_{1}$.

A prescribed amount of the polymer was dissolved in a mixed solvent of ethanol and tetrahydrofuran (in a weight ratio of $1: 1$ ) and mixed with purified and dried soil, and was dried to a constant weight under a reduced pressure at room temperature to remove solvents.

We performed biodegradation of PST- $c o-\mathrm{BVP}(\mathrm{Cl})$ by treatment with activated sludge in soil. We mixed a prescribed amount of washed activated sludge and artificial sewage with test soil that contained the test polymer. We added artificial sewage, $0.2 \mathrm{~g}$ in COD per gram of the test polymer, to assist the biodegradation. The total amounts of water and activated sludge were settled to be $200 \mathrm{~mL} \mathrm{~kg}^{-1}$ and $14.2 \mathrm{~g} \mathrm{~kg}^{-1}$ (in wet weight), respectively. We allowed the mixture to stand at room temperature. After a prescribed time, we recovered the remained polymer by extraction with a mixture of ethanol and tetrahydrofuran in weight ratio of $1: 1$ for $48 \mathrm{~h}$ using a Soxhlet extraction apparatus. We removed fine soil particles contained in the extractive by centrifugation at $2000 \mathrm{~g}$ for $20 \mathrm{~min}$. We repeated this centrifugation three times, and removed solvents by evaporation using a rotary evaporator. We added ethyl acetate to the residue to isolate the recovered polymer sample, and dried the isolated polymer to a constant weight under a reduced pressure at room temperature. Low molecular weight oligomers and other organic materials soluble in ethyl acetate were not included in the residual weight. Before these experiments, we performed a series of experiments to ascertain the reliability of the recovery procedure.

Figure 7 and Figure 8 show time course of weight reduction of polymers during the biological treatment. Here, residual weight is the total weight of polymeric materials recovered after the biological treatment. Figure 9 and 
Figure 10 show time course of $t \ln 2 / \ln a /(a-x)$ during the biological treatment. Here, $t$ is treatment time (days), $a$ is initial amount of the polymer $\left(\mathrm{g} \mathrm{kg}^{-1}\right)$, and $x$ is weight loss of polymer during the treatment time $t$.

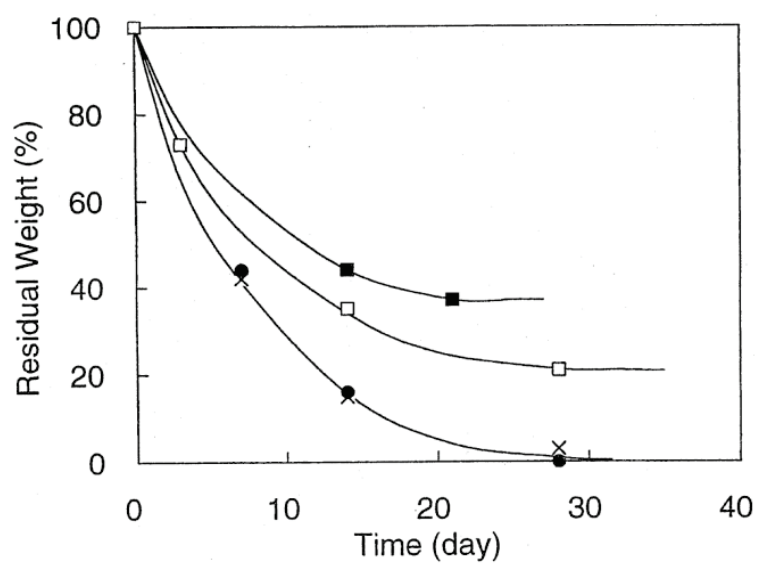

Figure 7. Time course of weight reduction of PST-co-BVP(Cl) during the biological treatment with activated sludge in soil at room temperature (amount of polymer sample is given in parentheses): $(X) \mathrm{PST}_{1}-\mathrm{co}-\mathrm{BVP}(\mathrm{Cl})_{1}\left(0.5 \mathrm{~g} \mathrm{~kg}^{-1}\right)$,

(•) $\mathrm{PST}_{1}-\mathrm{Co}-\mathrm{BVP}(\mathrm{Cl})_{1}\left(1.0 \mathrm{~g} \mathrm{~kg}^{-1}\right)$, ( $\left.\square\right) \mathrm{PST}_{2}-\mathrm{co}-\mathrm{BVP}(\mathrm{Cl})_{1}\left(0.5 \mathrm{~g} \mathrm{~kg}^{-1}\right)$, and $(\square) \mathrm{PST}_{2}-\mathrm{Co}-\mathrm{BVP}(\mathrm{Cl})_{1}\left(1.0 \mathrm{~g} \mathrm{~kg}^{-1}\right)$.

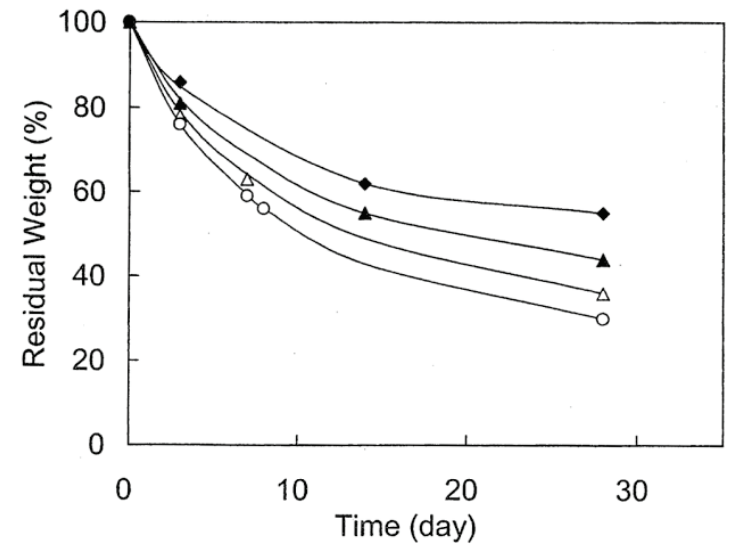

Figure 8. Time course of weight reduction of PST-co-BVP during the treatment with activated sludge in soil at room temperature (amount of polymer sample used for the treatment was $\left.0.5 \mathrm{~g} \mathrm{~kg}^{-1}\right):(0) \mathrm{PST}_{3}-\mathrm{Co}-\mathrm{BVP}(\mathrm{Cl})_{1},(\Delta) \mathrm{PST}_{4}-\mathrm{Co}-\mathrm{BVP}(\mathrm{Cl})_{1},(\boldsymbol{\Delta}) \mathrm{PST}_{5}-\mathrm{Co}^{-}$ $\mathrm{BVP}(\mathrm{Cl})_{1}$, and $(\diamond) \mathrm{PST}_{8}-\mathrm{Co}-\mathrm{BVP}(\mathrm{Cl})_{1}$. 


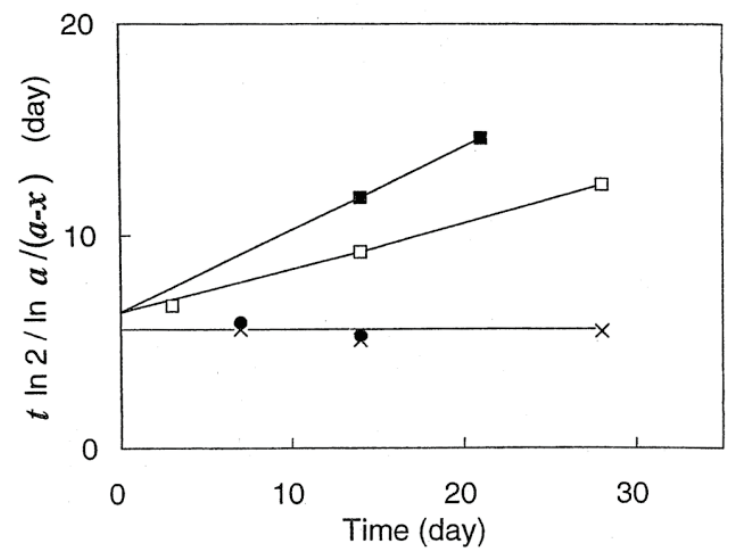

Figure 9. Time course of $t \ln 2 / \ln a /(a-x)$ during the treatment of PST-co-BVP(Cl) with activated sludge in soil at room temperature (the amount of polymer sample is given in parentheses): $(X) \mathrm{PST}_{1}-\mathrm{Co}-\mathrm{BVP}(\mathrm{Cl})_{1}\left(0.5 \mathrm{~g} \mathrm{~kg}^{-1}\right),(\bullet) \mathrm{PST}_{1}-\mathrm{Co}-\mathrm{BVP}(\mathrm{Cl})_{1}\left(1.0 \mathrm{~g} \mathrm{~kg}^{-1}\right)$,

$(\square) \mathrm{PST}_{2}-\mathrm{Co}-\mathrm{BVP}(\mathrm{Cl})_{1}\left(0.5 \mathrm{~g} \mathrm{~kg}^{-1}\right)$, (匹) $\mathrm{PST}_{2}-\mathrm{Co}-\mathrm{BVP}(\mathrm{Cl})_{1}\left(1.0 \mathrm{~g} \mathrm{~kg}^{-1}\right)$.

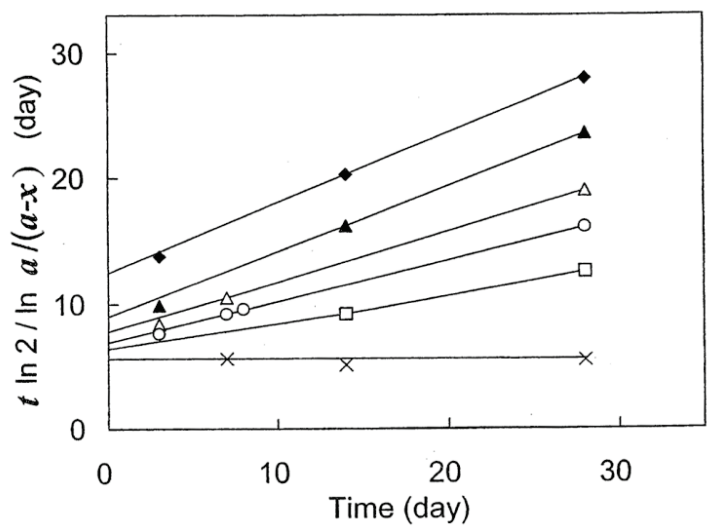

Figure 10. Time course of $t \ln 2 / \ln a /(a-x)$ during the treatment with activated sludge in soil at room temperature (amount of polymer sample was $0.5 \mathrm{~g} \mathrm{~kg}^{-1}$ ):

$(X) \mathrm{PST}_{1}-c o-\mathrm{BVP}(\mathrm{Cl})_{1},(\square) \mathrm{PST}_{2}-c o-\mathrm{BVP}(\mathrm{Cl})_{1},(\circ) \mathrm{PST}_{3}-c o-\mathrm{BVP}(\mathrm{Cl})_{1}$,

$(\Delta) \mathrm{PST}_{4}-c o-\mathrm{BVP}(\mathrm{Cl})_{1},(\boldsymbol{\Delta}) \mathrm{PST}_{5}-c o-\mathrm{BVP}(\mathrm{Cl})_{1},(\diamond) \mathrm{PST}_{8}-c o-\mathrm{BVP}(\mathrm{Cl})_{1}$.

Closed circles and cross marks in Figure 7 show time course of weight reduction of $\mathrm{PST}_{1}-\mathrm{Co}-\mathrm{BVP}(\mathrm{Cl})_{1}$ during the treatment. Here, cross marks and closed circles show the results obtained with 0.5 and $1.0 \mathrm{~g} \mathrm{~kg}^{-1}$ of $\mathrm{PST}_{1}-\mathrm{co}-$ $\mathrm{BVP}(\mathrm{Cl})_{1}$, respectively. Above two time courses were very close. Closed circles and cross marks in Figure 9 show time course of $t \ln 2 / a /(a-x)$ during the biological treatment of $\mathrm{PST}_{1}-\mathrm{Co}-\mathrm{BVP}(\mathrm{Cl})_{1}$. Cross marks and closed circles show the results obtained with 0.5 and $1.0 \mathrm{~g} \mathrm{~kg}^{-1}$ of the copolymer, respectively. 
These time courses were close and did not depend on $t$. These experimental results indicated that biodegradation of $\mathrm{PST}_{1}-\mathrm{CO}-\mathrm{BVP}(\mathrm{Cl})_{1}$ followed first-order kinetics under the conditions of biological treatment. Addition of $1.0 \mathrm{~g} \mathrm{~kg}^{-1}$ of $\mathrm{PST}_{1}-\mathrm{Co}-\mathrm{BVP}(\mathrm{Cl})_{1}$ appeared to be not too much, and was within the ability of activated sludge used for the biological treatment. The half-life of $\mathrm{PST}_{1}$-co$\operatorname{BVP}(\mathrm{Cl})_{1}$ during the biological treatment was evaluated 5.6 days.

Open squares and closed squares of Figure 7 show time course of weight reduction of $\mathrm{PST}_{2}-\mathrm{Co}-\mathrm{BVP}(\mathrm{Cl})_{1}$ during the treatment, where amount of polymer sample was 0.5 and $1.0 \mathrm{~g} \mathrm{~kg}^{-1}$, respectively. Weight reduction was faster when smaller amount of polymer sample was used (open squares), making a sharp contrast with $\mathrm{PST}_{1}-\mathrm{co}-\mathrm{BVP}(\mathrm{Cl})_{1}$ where weight reduction did not depend on the amount of polymer sample. The difference of $\mathrm{PST}_{1}-\mathrm{Co}-\mathrm{BVP}(\mathrm{Cl})_{1}$ from $\mathrm{PST}_{2}-\mathrm{Co}$ $\mathrm{BVP}(\mathrm{Cl})_{1}$ appears to be derived from the more difficult biodegradation of $\mathrm{PST}_{2}$ $c o-\mathrm{BVP}(\mathrm{Cl})_{1}$ than that of $\mathrm{PST}_{1}-c 0-\mathrm{BVP}(\mathrm{Cl})_{1}$. Addition of $0.5 \mathrm{~g} \mathrm{~kg}^{-1}$ of polymer sample of $\mathrm{PST}_{2}-\mathrm{Co}-\mathrm{BVP}(\mathrm{Cl})_{1}$ appeared to be still too much with respect to the degradation ability of microbes contained in the activated sludge used in the biological treatment.

Open squares and closed squares of Figure 9 show the time course of $t \ln 2 / \ln a /(a-x)$ during the biological treatment of $\mathrm{PST}_{2}-\mathrm{Co}-\mathrm{BVP}(\mathrm{Cl})_{1}$, where concentrations of polymer were 0.5 and $1.0 \mathrm{~g} \mathrm{~kg}^{-1}$, respectively. Degradation of $\mathrm{PST}_{2}$ - $\mathrm{Co}$-BVP $(\mathrm{Cl})_{1}$ did not follow first-order kinetics under the treatment conditions. This result indicates that addition of $0.5 \mathrm{~g} \mathrm{~kg}^{-1}$ of $\mathrm{PST}_{2}-\mathrm{Co}-\mathrm{BVP}(\mathrm{Cl})_{1}$ was still overloading with respect to the ability of microbes contained in activated sludge used in the treatment system. However, slope of the linear relationship shown in Figure 9 was lower in the case of open squares, that is, when smaller amount of $\mathrm{PST}_{2}-\mathrm{Co}-\mathrm{BVP}(\mathrm{Cl})_{1}$ was used. This result suggests that the linear relationship shown in Figure 9 will become independent on the treatment time when amount of the polymer sample is sufficiently small. In addition, linear relationship shown in Figure 9 by open squares coincides with that shown by closed squares at the treatment time of zero. This result suggests that the linear relationship shown by Figure 9 may give 6.4 days as the half-life under the ultimate conditions where a sufficiently small amount of $\mathrm{PST}_{2}-\mathrm{Co}-\mathrm{BVP}(\mathrm{Cl})_{1}$ is used. On the basis of this assumption, we evaluated halflife of $\mathrm{PST}_{2}-\mathrm{Co}$-BVP(Cl$)_{1}$ to be 6.4 days when amount of polymer sample was sufficiently small and did not exceed the degradation ability of microorganisms contained in the activated sludge used in the treatment system.

We performed biodegradations of $\mathrm{PST}_{3}-\mathrm{Co}-\mathrm{BVP}(\mathrm{Cl})_{1}, \mathrm{PST}_{4}-\mathrm{Co}-\mathrm{BVP}(\mathrm{Cl})_{1}, \mathrm{PST}_{5}-$ $c o$-BVP $(\mathrm{Cl})_{1}$ and $\mathrm{PST}_{8}-\mathrm{Co}-\mathrm{BVP}(\mathrm{Cl})_{1}$ by activated sludge in soil using $0.5 \mathrm{~g} \mathrm{~kg}^{-1}$ of polymer samples. Open circle in Figures 8 and 10 show the experimental results using $\mathrm{PST}_{3}-\mathrm{Co}-\mathrm{BVP}(\mathrm{Cl})_{1}$. Half-life was evaluated to be 6.9 days. Open triangles of Figures 8 and 10 show the experimental results using $\mathrm{PST}_{4}$-CO$\mathrm{BVP}(\mathrm{Cl})_{1}$. Half-life was evaluated to be 7.8 days. Closed triangle of Figures 8 and 10 show the experimental results using $\mathrm{PST}_{5}-\mathrm{Co}-\mathrm{BVP}(\mathrm{Cl})_{1}$. Half-life was evaluated to be 9.0 days. Closed rhombuses of Figures 8 and 10 show the 
experimental results using $\mathrm{PST}_{8}-\mathrm{co}-\mathrm{BVP}(\mathrm{Cl})_{1}$. Half-life was evaluated to be 12.5 days.

The slope of Figures 9 and 10 reflects biodegradability of the oligomer portion of PST-co-BVP(Cl). Strong biodegradability of the oligomer portion lowers the slope, whereas poor biodegradability of the oligomer portion raises the slope.

We investigated the mode of chain scission of $\mathrm{PST}_{3}-\mathrm{Co}-\mathrm{BVP}(\mathrm{Cl})_{1}$ during the treatment with activated sludge in soil in detail. Since the recovered polymer samples of PST-co-BVP(Cl) did not exhibit perceivable change in the elementary composition, we estimated the rate of chain shortening of the recovered polymer simply on the basis of the rate of reduction of molecular weight, that is, by division of molecular weight of recovered polymer by that of the polymer before the biological treatment.

In the case where random scission at inside of polymer chain predominated in biodegradation of polymer, reduction of molecular weight may predominate over that of gravimetric weight of recovered polymers. On the other hand, in the case where uniformly successive scission from end of polymer chain predominated, reduction of molecular weight and that of gravimetric weight of recovered polymer may occur in parallel.

Experimental results concerned with the mode of chain scission in biodegradation of $\mathrm{PST}_{3}-\mathrm{Co}-\mathrm{BVP}(\mathrm{Cl})_{1}$ are summarized in Figure 11. Concentration of used polymer sample was $0.5 \mathrm{~g} \mathrm{~kg}^{-1}$. Closed circle show time course of residual weight of polymer and open circle show time course of reduction of molecular weight of recovered polymer. Obviously, reduction of molecular weight much predominated over reduction of gravimetric weight of polymer during the biodegradation of $\mathrm{PST}_{3}-\mathrm{Co}-\mathrm{BVP}(\mathrm{Cl})_{1}$. This result clearly indicates that cleavage at $\mathrm{BVP}(\mathrm{Cl})$ portion much predominated over that of trimer portion in the biodegradation of $\mathrm{PST}_{3}-\mathrm{Co}-\mathrm{BVP}(\mathrm{Cl})_{1}$. Biodegradation of trimer of styrene appears to be much more difficult than that of $\mathrm{BVP}(\mathrm{Cl})$, although dimer of styrene is biodegradable [34]. It is obvious that $\mathrm{BVP}(\mathrm{Cl})$ is not only a biodegradable chemical unit useful to connect biodegradable oligomers, but also facilitates biodegradation of the connected oligomer portion. 


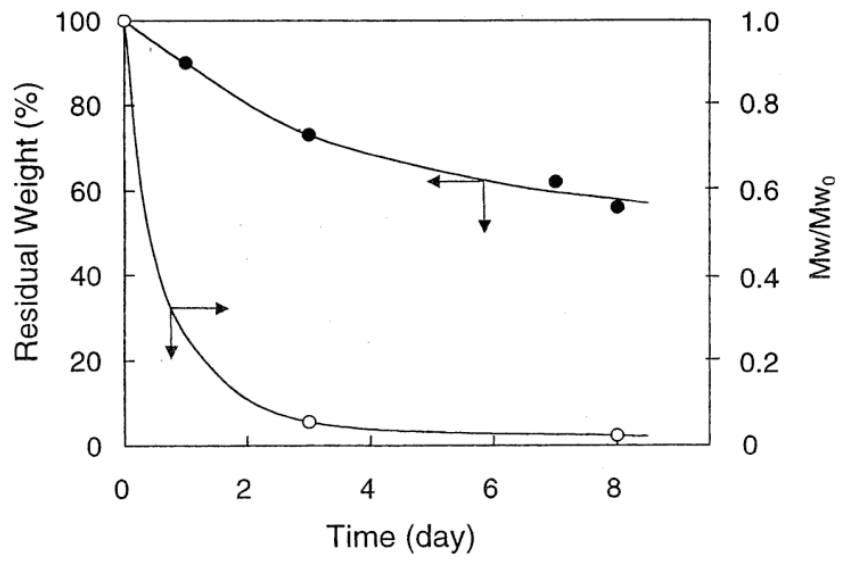

Figure 11. Time course of $(\bullet)$ residual weight and $(\circ)$ rate of reduction of molecular weight of the recovered polymer during the treatment of $\mathrm{PST}_{3}-\mathrm{Co}-\mathrm{BVP}(\mathrm{Cl})_{1}$ with activated sludge in soil at room temperature. Mw is molecular weight of recovered polymer and $\mathrm{Mw}_{0}$ is molecular weight of the polymer before the biological treatment.

The amount of polymer sample used for the treatment was $0.5 \mathrm{~g} \mathrm{~kg}^{-1}$.

\subsection{BIODEGRABILITY OF POLY(ACRYLONITRILE) THAT CONTAINS BVP(Cl) IN THE MAIN CHAIN}

We investigated biodegradation of copolymer of acrylonitrile with BVP $(\mathrm{Cl})$, PAN-co-BVP(Cl), by the treatment with activated sludge in soil [36]. We used the following five sorts of polymers; $\mathrm{PAN}_{2}-\mathrm{Co}-\mathrm{BVP}(\mathrm{Cl})_{1}$ that contained 33.0 mole $\%$ of $\mathrm{BVP}(\mathrm{Cl}), \mathrm{PAN}_{7}-\mathrm{Co}-\mathrm{BVP}(\mathrm{Cl})_{1}$ that contained 12.3 mole $\%$ of $\mathrm{BVP}(\mathrm{Cl}), \mathrm{PAN}_{9}-\mathrm{CO}-\mathrm{BVP}(\mathrm{Cl})_{1}$ that contained 10.0 mole $\%$ of $\mathrm{BVP}(\mathrm{Cl}), \mathrm{PAN}_{14}-\mathrm{CO}-$ $\mathrm{BVP}(\mathrm{Cl})_{1}$ that contained 6.6 mole $\%$ of $\mathrm{BVP}(\mathrm{Cl})$, and $\mathrm{PAN}_{32}-\mathrm{Co}-\mathrm{BVP}(\mathrm{Cl})_{1}$ that contained 3.0 mole \% of BVP(Cl). For comparison, we also used homo-polymer of acrylonitrile, PAN, and copolymer of acrylonitrile with 4-vinylpyridine, $\mathrm{PAN}_{7}-\mathrm{Co}-\mathrm{VP}_{1}$, that contained 13.2 mole \% of 4-vinylpyridine.

Polymer sample (100 mg) was dissolved in dimethylformamide (DMF, $10 \mathrm{~mL}$ ), and was mixed with washed and dried test soil (50 g). The mixture was then placed in a desiccator, and DMF was removed by drying under a reduced pressure to constant weight.

Washed activated sludge $(0.71 \mathrm{~g}$ in wet weight) and an artificial sewage (100 mg in COD) were mixed with test soil (50 g). Total amount of water in the test soil was $200 \mathrm{~mL} \mathrm{~kg}^{-1}$. The mixture was allowed to stand at room temperature. After a prescribed time, the remained polymer was recovered by extraction with DMF using a Soxhlet extraction apparatus at room temperature for $100 \mathrm{~h}$. Fine soil particles contained in the extractive were removed by 
centrifugation. The supernatant was placed in a rotary evaporator, and DMF was removed by evaporation. Ethyl acetate was added to the residue and the recovered polymer was precipitated, and was dried to constant weight under a reduced pressure. A series of control experiments were performed to ascertain reliability of the recovery procedure. Recovered polymer samples of PAN-co$\mathrm{BVP}(\mathrm{Cl})$ did not exhibit a perceivable change of elementary composition.

Figure 12 shows time course of weight reduction during the biological treatment. Here, residual weight of polymer recovered after the biological treatment was obtained by precipitation using ethyl acetate and was purified. Therefore, low molecular weight oligomers and other organic materials soluble in ethyl acetate were not included. As shown in Figure 12, weight reduction was not observed in the cases of PAN (cross marks) and $\mathrm{PAN}_{7}-\mathrm{CO}_{-} \mathrm{VP}_{1}$ (closed circles), respectively. In the absence of $\mathrm{BVP}(\mathrm{Cl})$, biodegradation was not observed, similarly to the cases of polystyrene, poly(methyl methacrylate), poly(vinyl acetate), and polyacrylamide.

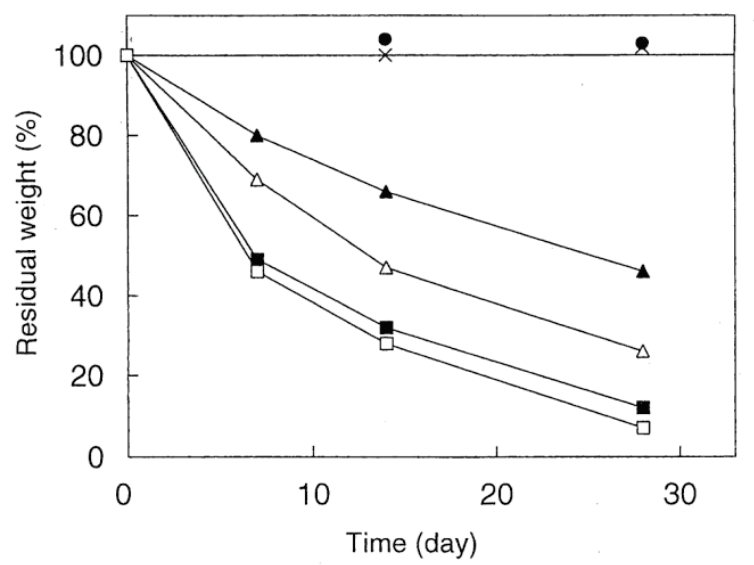

Figure 12. Time course of weight of polymer recovered after the treatment with activated sludge in soil at room temperature. Initial amount of polymer sample, $2.0 \mathrm{~g} \mathrm{~kg}^{-1}$; amount of artificial sewage added to the treatment system, $2.0 \mathrm{~g} \mathrm{~kg}^{-1}$ in COD; amount of water, $200 \mathrm{~mL} \mathrm{~kg}^{-1}$. Intrinsic viscosities of polymer samples determined before the biological treatment are given in parentheses in $\mathrm{dL} \mathrm{g}^{-1}$. In the cases of PAN$c o-\mathrm{BVP}(\mathrm{Cl})$, the given viscosities are those of corresponding PAN-co-VP determined prior to the reaction with benzyl chloride. $(X)$ PAN (0.65); $(\bullet)$ PAN-co-VP (0.75);

( $\Delta$ ) $\mathrm{PAN}_{32}-\mathrm{Co}-\mathrm{BVP}(\mathrm{Cl})_{1}(0.69) ;(\triangle) \mathrm{PAN}_{14}-\mathrm{Co}-\mathrm{BVP}(\mathrm{Cl})_{1}(0.59)$;

(匹) $\mathrm{PAN}_{7}-\mathrm{Co}-\mathrm{BVP}(\mathrm{Cl})_{1}(0.66)$; and $(\square) \mathrm{PAN}_{2}-\mathrm{Co}-\mathrm{BVP}(\mathrm{Cl})_{1}(1.10)$.

On the contrary, $\mathrm{PAN}_{32}-\mathrm{Co}-\mathrm{BVP}(\mathrm{Cl})_{1}$ (closed triangles) exhibited obvious weight reduction during the biological treatment. PAN was splendidly transfigured to biodegradable polymer by insertion of only 3 mole $\%$ of BVP(Cl) into the main chain. In this case, average number of acrylonitrile unit in the oligomer portion 
was 32. Much more splendid weight reductions were observed in the cases of $\mathrm{PAN}_{14}-\mathrm{CO}-\mathrm{BVP}(\mathrm{Cl})_{1}$ (open triangles), $\mathrm{PAN}_{7}-\mathrm{CO}-\mathrm{BVP}(\mathrm{Cl})_{1}$ (closed squares), and $\mathrm{PAN}_{2}-\mathrm{Co}-\mathrm{BVP}(\mathrm{Cl})_{1}$ (open squares), respectively.

Figure 13 shows time course of $t \ln 2 / \ln a /(a-x)$ during the biological treatment. Here, $t$ is treatment time, $a$ is initial amount of polymer sample, and $x$ is weight loss of the polymer during the treatment time $t$. Time course of weight reduction was shown to follow approximately the first order kinetics, although the above function increased a little bit with the treatment time $t$, and we evaluated half-lives of these copolymers by extension of the relation to the treatment time $t$ zero. Half-lives of $\mathrm{PAN}_{2}-\mathrm{Co}-\mathrm{BVP}(\mathrm{Cl})_{1}, \mathrm{PAN}_{7}-\mathrm{Co}-\mathrm{BVP}(\mathrm{Cl})_{1}, \mathrm{PAN}_{14}$ $c o-\mathrm{BVP}(\mathrm{Cl})_{1}$, and $\mathrm{PAN}_{32}-\mathrm{co}-\mathrm{BVP}(\mathrm{Cl})_{1}$ were evaluated to be about $6.7,7.2,12.4$ and 21 days, respectively, when sufficiently small amount of polymer samples were used.

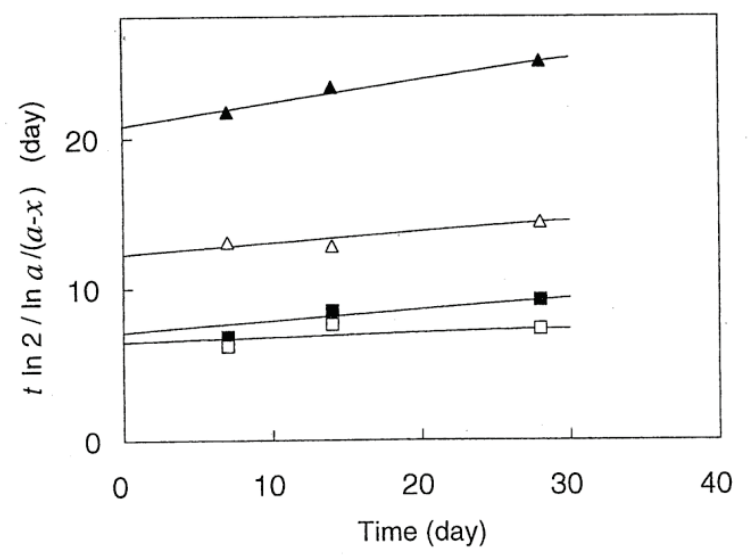

Figure 13. Time course of $t \ln 2 / \ln a /(a-x)$ during the treatment of PAN-co-BVP(Cl) with activated sludge in soil: $t$, treatment time; $a$, initial amount of polymer sample; $x$, weight loss of polymer sample during the treatment time $t$. $(\boldsymbol{\Delta}) \mathrm{PAN}_{32}-\mathrm{Co}-\mathrm{BVP}(\mathrm{Cl})_{1}$;

$(\triangle) \mathrm{PAN}_{14}-\mathrm{Co}-\mathrm{BVP}(\mathrm{Cl})_{1} ;(\mathbf{a}) \mathrm{PAN}_{7}-\mathrm{Co}-\mathrm{BVP}(\mathrm{Cl})_{1}$; and $(\square) \mathrm{PAN}_{2}-\mathrm{Co}-\mathrm{BVP}(\mathrm{Cl})_{1}$.

These results indicate that biodegradation of PAN-co-BVP(Cl) is not limited to the portion of $\mathrm{BVP}(\mathrm{Cl})$, and oligomer portion also exhibits exhaustive biodegradation when the chain is sufficiently short. In biodegradation of $\mathrm{PAN}_{32}-\mathrm{CO}-\mathrm{BVP}(\mathrm{Cl})_{1}$, closed triangles of Figure 12 indicated that the weight reduction during 28 days (54\%) much surpassed the amount of BVP(Cl) (3.0 mole \%, corresponded to about 12 weight \%). Biodegradation of oligomers of acrylonitrile was shown to be not limited to low oligomer, and even 32-mer still shows significant biodegradability when BVP(Cl) was inserted into the main chain. Half-life of $\mathrm{PAN}_{32}-\mathrm{Co}$ - $\mathrm{BVP}(\mathrm{Cl})_{1}$ was evaluated to be about 21 days. This half-life means that $99.9 \%$ of the polymer will disappear during 7 months of the biological treatment. These observations prompted us 
to consider that $\mathrm{BVP}(\mathrm{Cl})$ acts as not only a highly biodegradable chemical unit useful to connect biodegradable oligomers, but also acts as a functional group that facilitates biodegradation of the connected oligomer portion. This method is a epoch-making technology that transfigures poorly biodegradable vinyl polymers to strongly biodegradable vinyl polymers.

We investigated mode of chain scission of PAN-co-BVP(Cl) during the biological treatment in detail using the following four types of polymer samples having a similar degree of polymerization: $\mathrm{PAN}_{7}-\mathrm{Co}-\mathrm{BVP}(\mathrm{Cl})_{1}, \mathrm{PAN}_{9}-\mathrm{CO}-$ $\mathrm{BVP}(\mathrm{Cl})_{1}, \mathrm{PAN}_{14}-\mathrm{CO}-\mathrm{BVP}(\mathrm{Cl})_{1}$, and $\mathrm{PAN}_{32}-\mathrm{Co}-\mathrm{BVP}(\mathrm{Cl})_{1}$. Viscosity average degrees of polymerization of these copolymer samples were $710,710,610$, and 770 , respectively. Experimental conditions of the biological treatment were the same as described above. Closed circles in Figure 14 show the relation between content of $\mathrm{BVP}(\mathrm{Cl})$ and residual weight after two weeks of the biological treatment. Open circles in Figure 14 show the relation between content of $\mathrm{BVP}(\mathrm{Cl})$ and rate of shortening of the estimated degree of polymerization, $\mathrm{DP} / \mathrm{DP}_{0}$. Here, $\mathrm{DP}_{0}$ and $\mathrm{DP}$ are estimated viscosity average degree of polymerization before the biological treatment and that of polymer samples recovered after two weeks of the biological treatment, respectively.

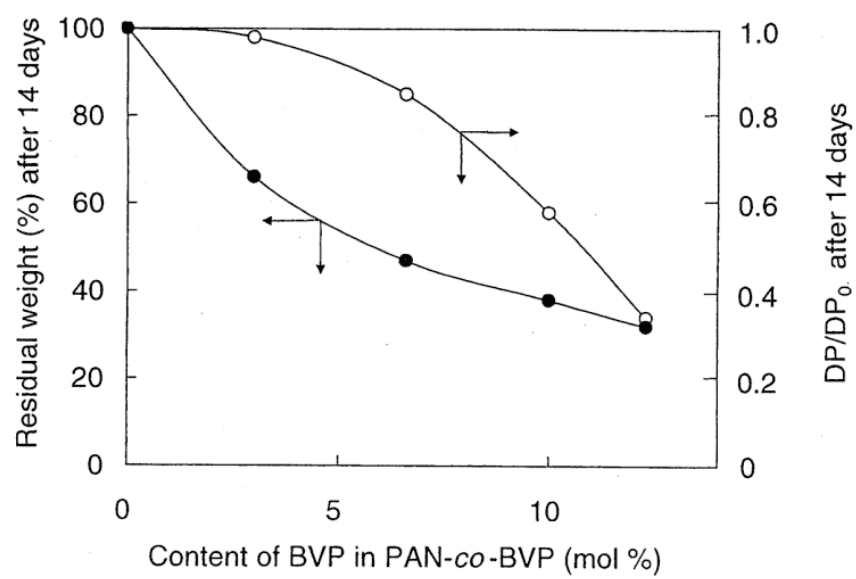

Figure 14. Influence of the content of BVP(Cl) in PAN-co-BVP(Cl) on residual weight $(\bullet)$ and rate of reduction of the estimated viscosity average degree of polymerization (O) of polymer samples after two weeks of the treatment. Here, $\mathrm{DP}_{0}$ and DP are the estimated viscosity average degree of polymerization before the biological treatment and that of the recovered polymer sample after two weeks of the biological treatment,

respectively. Experimental conditions of the biological treatment are same as in

Figure 12.

Figure 14 shows that weight reduction much predominated over reduction of molecular weight of polymer when content of BVP(Cl) was low. For example, in 
the case of $\mathrm{PAN}_{32}-\mathrm{Co}-\mathrm{BVP}(\mathrm{Cl})_{1}$, residual weight reduced to $66 \%$ after two weeks of the treatment, but chain length of the recovered polymer was $98 \%$ of the original length at this stage. This result indicates that the amount of low molecular weight fraction was very small in the recovered polymer and reflects a characteristic feature of the biodegradation. Biodegradation of lower molecular weight polymer predominated. When biodegradation started, the shortened polymers seem to undergo predominant biodegradation, leaving high molecular weight polymers unchanged.

In the case of $\mathrm{PAN}_{7}-\mathrm{Co}-\mathrm{BVP}(\mathrm{Cl})_{1}$, however, residual weight reduced to $32 \%$ after two weeks of the treatment, and chain length of recovered polymer was $34 \%$ of original length at this stage. Weight reduction balanced with shortening of polymer chain, and uniformly successive scission from the end of polymer chain appeared to be suitable for the mechanisms of biodegradation. This observation suggests that biodegradability of oligomer portion of acrylonitrile stands comparison with that of $\mathrm{BVP}(\mathrm{Cl})$ when the oligomer portion was shorter than heptamer. Oligomers of acrylonitrile appear to be much more biodegradable than oligomers of styrene.

\subsection{RECYCLING USE OF SYNTHETIC POLYMERS WITHOUT LEAVING WASTES INTO NATURAL ENVIRONMENT}

Chemists and chemical industry should become aware of their responsibility for the serious fact that most of synthetic polymers are poorly biodegradable and severely pollute the natural environment after use [1]. Grant of strong biodegradability to synthetic polymers is useful to protect natural abundant environment from pollution by wasted synthetic polymers. Insertion of BVP into main chain exerts strong biodegradability to vinyl polymers, but this technology cannot transfigure all sorts of synthetic polymers biodegradable.

Therefore, prevention of waste of used synthetic polymers is greatly important in protection of natural environment from pollution by wasted synthetic polymers. In the case of synthetic polymers where durability is absolutely more important than biodegradability, prevention of waste after use is inevitable. For the solution of this subject, recycling use of synthetic polymers is inevitable. 


\subsubsection{Zero-emission use of synthetic polymers to prevent pollution of natural environment by wasted synthetic polymers}

In the protection of natural abundant environment from serious pollution by wasted synthetic polymers, zero-emission use of synthetic polymers is inevitable. Use of resource materials can be roughly classified into one-way use and recycling use. One-way use leaves waste such as micro-plastics at the final stage, and pollutes natural environment. In contrast, recycling use decreases the amount of abandoned wastes. Key point of effective retrenchment of the amount of wasted synthetic polymers is drastic conversion of one-way use to recycling use of synthetic polymers. Prevention of abandon of used polymers is exceedingly more important than appropriate treatment of abandoned used polymers.

\subsubsection{Grade of recycling use of synthetic polymers}

Recycling use of synthetic polymer is not uniform, and can be classified into five grades based on the degree of reduction of wastes. Grade up of recycling use of synthetic polymers decreases wastes of the polymers. Thermal recycle of used polymer does not supply raw materials necessary to prepare the corresponding polymer, and is not worth as recycling use of synthetic polymer. Substance of thermal recycle of used polymers is utilization of used polymers as fuels.

Grade 1 is deceptive recycle that does not decrease waste, i.e., reutilization for different purpose such as utilization of used PET (polyethylene terephthalate) bottle as fiber or sheet. This recycled fiber or sheet is wasted after use, and does not decrease wastes.

Grade 2 is material recycle and chemical recycle. Material recycle accompanies deterioration of quality of reclaimed polymers, and supplement of new polymer is indispensable in re-preparation of corresponding polymers to compensate this quality deterioration, and is called as cascade-type recycle. Chemical recycle can return used polymers to raw materials of the corresponding polymer, but practice of chemical recycle is limited to some types of synthetic polymers. In the case of vinyl polymers, de-polymerization of used polymer can supply raw material of the polymer, but yields of the corresponding monomer are not sufficient except for methyl methacrylate and styrene. Efficient and individual collection system of used polymers is inevitable in practice of material recycle and chemical recycle.

Grade 3 is reuse that considerably decreases wastes. For example, when PET bottle is reused 30 times, amount of resource materials required for production of PET bottle decreases to $1 / 30$, and amount of wastes due to used PET bottle also decreases to $1 / 30$. Individual collection system of used synthetic polymers such as deposit system is necessary in practice of efficient reuse of polymers. 
Grade 4 is reduction that further decreases wastes of polymers by miniaturization, lightening and prolongation of using period of products made of polymers. Elevation of durability of polymers that consists products elongates the using period of products and reduces wastes. Repair of products, exchange of broken portion of products, and exchange of outstripped module of products with progressed module elongates using period of products and retrenches wastes.

Reduction of total environmental load derived from industrial products is evaluated through total life of industrial products from mining of resource materials, manufacturing of products, use of products, and final treatment of used products. An important index of retrenchment of the total environmental load of industrial products during the total life of product is known as "factor X".

Grade 5 is perfect recycle that can cope with exhaustion of resource materials, and can manufacture products without use of new resource materials. In the case of exhausted resource materials, manufacturing of industrial products without use of new resource materials is unavoidable. A part of rare metals is already reached to this situation, and wastes of industrial products that contain the exhausted resource materials are called as "urban mine". The valuable exhausted resource materials contained in the corresponding used products are taken out and can be used for repeated manufacture of products.

\subsubsection{Closely connected cooperation of artery industry with venous industry required by efficient recycling of resource materials}

Manufacturing industries are roughly classified into artery industry and venous industry. Artery industries supply products using resource materials and recycled materials, and venous industries take out materials from used products and reclaim collected materials, and supply the reclaimed materials to artery industries. In the case where reclamation of materials taken out from used products is easily practiced, recycling use of materials can be easily accomplished. In contrast, in the case where taking out of materials from used products is difficult or reclamation of collected materials is difficult, venous industries are obliged to give up recycling of resource materials, and used products lose their utility value and pollute natural environment as useless wastes. One-sided manufacturing of complicated products by artery industries obstructs recycling use of materials and promotes abandonment of useless wastes and increases the environmental load. Accurate separation of used products according to their sort and deposit system of used products to original producer strongly assist efficient practice of recycling use of resource materials and reduce environmental load. These improvements of recycling system require closely connected cooperation of artery industries with venous industries. Exhausted material that is indispensable for manufacture of 
industrial products is mainly contained in the corresponding used products, and recycling of used products at original factory is efficient. Large scale production by selfish artery industry leaves a lot of wastes that promote increase of environmental load, and should be controlled by strong pressure of public opinion.

Efficient recycling use of resource materials requires support of public society. Deposit system is efficient on practice of reuse of products. EPR (extended produced responsibility) system proposed by OECD prompts effective cooperation of artery industry with venous industry in practice of recycling use of resource materials.

\section{REFERENCES}

1. C. Moore, C. Philips, Plastic Ocean: How a Sea Captain's Chance Discovery Launched a Determined Quest to Save the Oceans, Avery (2011).

2. N. Kawabata, T. Hayashi, T. Matsumoto. Appl. Environ. Microbiol. 46 (1983) 203-210.

3. N. Kawabata, T. Hashizume, T. Matsumoto. Agric. Biol. Chem. 50 (1986) 1551-1555.

4. N. Kawabata, K. Yamazaki, T. Otake, I. Oishi, Y. Minekawa. Epidemiol. Infect. 105 (1990) 633-642.

5. N. Kawabata, T. Morigaki. Environ. Sci. Technol. 14 (1980) 1089-1093.

6. S.L. Daniels, L.L. Kempe. Chem. Eng. Prog. Symp. Ser. 62(69) (1966) 124-148.

7. N. Kawabata, T. Hayashi, M. Nishikawa. Bull. Chem. Soc. Jpn. 59 (1986) 2861-2863.

8. N. Kawabata, Y. Ueno, K. Torii, T. Matsumoto. Agric. Biol. Chem. 51 (1987) 1085-1090.

9. N. Kawabata, S. Nishimura, T. Yoshimura. Biotech. Bioeng. 35 (1990) 1000-1005.

10. B.H. Keswick, C.P. Gerba, H.L. DuPont, J.B. Rose. Appl. Environ. Microbiol. 47 (1984) 1290-1294.

11. P.T.B. Shaffer, T.G. Metcalf, O.J. Sproul. Appl. Environ. Microbiol. 40 (1980) 1115-1121.

12. N. Kawabata, I. Fujita, T. Inoue. J. Appl. Polym. Sci. 60 (1996) 911-917.

13. N. Kawabata, I. Ujino. React. Funct. Polym. 37 (1998) 213-218.

14. N. Kawabata, S. Kawato. Epidemiol. Infect. 121 (1998) 349-356.

15. N. Kawabata, M. Nishiguchi. Appl. Environ. Microbiol. 54 (1988) 2532-2535.

16. N. Kawabata, K. Takagishi, M. Nishiguchi. React. Polym. 10 (1989) 269-273.

17. N. Kawabata, T. Fuse. J. Appl. Polym. Sci. 100 (2006) 1618-1623.

18. N. Kawabata, W. Sakakura, Y. Nishimura. Biosci. Biotechnol. Biochem. 69 (2005) 537-543.

19. N. Kawabata, E. Tanabe. React. Funct. Polym. 65 (2005) 293-299.

20. N. Kawabata, T. Inoue, H. Tomita. Epidemiol. Infect. 108 (1992) 123-134.

21. N. Kawabata, K. Teramoto, T. Ueda. J. Microbiol. Methods. 15 (1992) 101-111.

22. N. Kawabata, K. Nakagawa. J. Ferment. Bioeng. 71 (1991) 19-23.

23. N. Kawabata, H. Hatanaka, H. Odaka. J. Ferment. Bioeng. 79 (1995) 317-322. 
24. N. Kawabata, H. Kishimoto, K. Yamanaka, T. Ikawa, I. Furusawa. Ann. Phytopathol. Soc. Jpn. 63 (1997) 253.

25. N. Kawabata, H. Kishimoto, T. Abe, I. Ikawa, K. Yamanaka, H. Ikeuchi, C. Kakimoto. Biosci. Biotechnol. Biochem. 69 (2005) 326-333.

26. N. Kawabata, D. Utihori, S. Fukuda, H. Funahashi. J. Appl. Polym. Sci. 51 (1994) 33-42.

27. I. Horazawa, Ed., Bio-Film Process, Shikosya, Tokyo (1982).

28. Y. Maeda. Hakko Kogaku Kaishi. 57 (1979) 114-124.

29. B.E. Rittmann. Environ. Sci. Technol. 21 (1987) 128-136.

30. A.-C. Albertson, Z.G. Banhidi. J. Appl. Polym. Sci. 25 (1980) 1655-1671.

31. S. Matsumura, S. Ii, H. Shigeno, T. Tanaka, F. Okuda, Y. Shimura, K. Toshima. Makromol. Chem. 194 (1993) 3237-3246.

32. N. Kawabata, T. Kurooka. J. Appl. Polym. Sci. 56 (1995) 509-516.

33. T. Suzuki, Y. Ichihara, M. Yamada, K. Tonomura. Agric. Biol. Chem. 37 (1973) 747-756.

34. A. Tsuchii, T. Suzuki, Y. Takahara. Agric. Biol. Chem. 41 (1977) 2417-2421.

35. N. Kawabata, C. Kakimoto, H. Ikeuchi. J. Appl. Polym. Sci. 100 (2006) 554-559.

36. N. Kawabata, K. Ohashi, T. Nishimura. J. Appl. Polym. Sci. 99 (2006) 852-857. 
